\title{
Molecular and morphological systematics of Bursatella leachii de Blainville, 1817 and Stylocheilus striatus Quoy \& Gaimard, 1832 reveal cryptic diversity in pantropically distributed taxa (Mollusca : Gastropoda : Heterobranchia)
}

\author{
Enrico Bazzicalupo (D) A, I, Fabio Crocetta ${ }^{\text {B }, ~ T e r r e n c e ~ M . ~ G o s l i n e r ~}{ }^{\text {C }}$, \\ Véronique Berteaux-Lecellier ${ }^{\mathrm{D}}$, Yolanda E. Camacho-García ${ }^{\mathrm{E}, \mathrm{F}, \mathrm{G}}$, \\ B. K. Sneha Chandran ${ }^{\mathrm{H}}$ and Ángel Valdés ${ }^{\mathrm{A}, \mathrm{I}}$ \\ A Department of Biological Sciences, California State Polytechnic University, 3801 West Temple Avenue, \\ Pomona, CA 91768, USA. \\ ${ }^{B}$ Department of Integrative Marine Ecology, Stazione Zoologica Anton Dohrn, Villa Comunale, \\ I-80121 Naples, Italy. \\ ${ }^{\mathrm{C}}$ Department of Invertebrate Zoology, California Academy of Sciences, 55 Music Concourse Drive, \\ San Francisco, CA 94118, USA. \\ DUMR 250/9220 ENTROPIE, IRD-CNRS-UR, LabEx Corail, 101, promenade Roger-Laroque, \\ Anse Vata BP A5, 98848 Nouméa cedex, New Caledonia. \\ EMuseo de Zoología, Escuela de Biología, Universidad de Costa Rica, Apartado 11501-2060, \\ San Pedro de Montes de Oca, San José, Costa Rica. \\ ${ }^{\mathrm{F}}$ Centro de Investigación en Ciencias del Mar y Limnología (CIMAR), Ciudad de la Investigación, \\ Universidad de Costa Rica, Apartado 11501-2060, San Pedro de Montes de Oca, San José, Costa Rica. \\ ${ }^{\mathrm{G}}$ Centro de Investigación en Estructuras Microscópicas (CIEMIC), Ciudad de la Investigación, \\ Universidad de Costa Rica, Apartado 11501-2060, San Pedro de Montes de Oca, San José, Costa Rica. \\ ${ }^{H}$ Department of Aquatic Biology and Fisheries, University of Kerala, Thiruvananthapuram, Kerala 695581, India. \\ 'Corresponding authors. Email: enricobazzical@gmail.com; aavaldes@cpp.edu
}

\begin{abstract}
The ragged sea hare (Bursatella leachii) and the long-tailed sea hare (Stylocheilus striatus) are two widely distributed species of benthic heterobranch sea slugs. In this paper, integrative taxonomic analyses have been conducted to detect possible cryptic diversity. Our results revealed that both nominal species are actually species complexes, consisting of five genetically distinct taxa. Two of them belong to the genus Bursatella and three to the genus Stylocheilus. The name B. leachii is retained for a widely distributed species, present in the Atlantic, the Mediterranean, and parts of the Indo-Pacific region. The name B. ocelligera is resurrected for the other species, restricted to the Indo-Pacific and co-occurring with $B$. leachii in that area. With the present data, it is not possible to test whether B. leachii and B. ocelligera have evolved allopatrically in the Atlantic and Indo-Pacific or sympatrically in the latter. Bursatella leachii has been able to maintain gene flow between the Atlantic and the Indo-Pacific Oceans, possibly because of a combined effect of the Agulhas Leakage process and the ability to survive the colder waters of South Africa. On the contrary, the three species of Stylocheilus are allopatric; the name S. striatus is retained for an Indo-Pacific species, while the names $S$. polyomma and $S$. rickettsi are resurrected for species inhabiting the Western Atlantic and the Eastern Pacific respectively. Finally, the discovery of a museum specimen mistakenly identified as B. leachii, but bearing a shell in its adult form, led to the resurrection of the genus Phycophila, previously synonymised with Aplysia. Phycophila euchlora, the only species described to date, is distributed in the Central and Western Pacific Ocean.
\end{abstract}

Received 26 September 2019, accepted 31 March 2020, published online 26 June 2020 


\section{Introduction}

The ragged and long-tailed sea hares of the genera Bursatella de Blainville, 1817 and Stylocheilus Gould, 1852 constitute a monophyletic group of Aplysiida (=Anaspidea) sea slugs, thee species of which are characterised by having inflated bodies covered with numerous ramified papillae and an absence of shells (Medina and Walsh 2000; Klussmann-Kolb 2004).

Bursatella is currently considered a monotypic genus, since Eales and Engel (1935) proposed the synonymisation of numerous available species names with Bursatella leachii de Blainville, 1817. Eales and Engel (1935) established a subspecies scheme based primarily on geographic distributions as well as on morphological differences. The subspecies recognised by Eales and Engel (1935) were: (1) B. leachii leachii de Blainville, 1817 from the Indo-Pacific; (2) B. leachii savigniana Andouin, 1826 from the Red Sea; (3) B. leachii africana Engel, 1926 from South Africa; (4) B. leachii rosea Engel, 1926 from West Africa; (5) B. leachii pleii Rang, 1828 from the West Indies; and (6) B. leachii lacinulata Gould, 1852 from Brazil. An additional subspecies from Ghana, B. leachii guineensis Bebbington, 1969, was later described by Bebbington (1969). However, recently published preliminary molecular analyses suggest that $B$. leachii is probably a single, nearly pantropical, species (Bazzicalupo et al. 2018). B. leachii is a benthic detritivore usually found in marine and estuarine protected bays grazing on muddy or sandy bottoms (Ramos et al. 1995; Clarke 2006).

Contrary to Bursatella, Stylocheilus is represented by two circumtropical species (Rudman 1999). The long-tailed sea hare, Stylocheilus striatus Quoy \& Gaimard, 1832, is a benthic herbivore specialised in feeding on the green-blue algae Lyngbya majuscula Harvey ex Gomont (see Paul and Pennings 1991). S. striatus has been reported from tropical and subtropical coastal regions around the world (Marcus 1972; Bebbington 1974, 1977), often incorrectly cited as S. longicaudus (see Rudman 1999). The second species, Stylocheilus longicaudus (Quoy \& Gaimard, 1825), often incorrectly cited as S. citrinus (see Rudman 1999), is a pelagic species associated with drifting algae, and also has a pantropical range (Marcus 1972; Rudman 1999).

The currently accepted species-level classification of Bursatella and Stylocheilus relies mainly on morphological taxonomic approaches. In the case of Bursatella, despite the fact that distinct geographic subspecies have been recognised, their taxonomic status remains controversial (Rudman 2007). In the case of Stylocheilus, studies based on morphological data have not revealed consistent differences between populations from different ocean basins (Bebbington 1974, 1977). Integrative taxonomy applied to other groups of benthic sea hares has shown that widely distributed species of sea hares constitute species complexes (Alexander and Valdés 2013; Valdés et al. 2017; Golestani et al. 2019). Thus, considering the extensive ranges of both $B$. leachii and $S$. striatus across different ocean basins, it is likely that the biodiversity of these two taxa is currently underestimated.

Bursatella and Stylocheilus have been the subject of research in the fields of biomedical chemistry, ecology, and neuroscience. Bioactive chemical compounds extracted from both Bursatella and Stylocheilus have been tested for possible cytotoxic, anti-inflammatory, and antiviral properties (e.g. Rose et al. 1978; Gopichand and Schmitz 1980; Gallimore and Scheuer 2000; Rajaganapathi et al. 2002). Ecological studies centred on feeding preference behaviour (Clarke 2006), chemical defence acquisition (Paul and Pennings 1991; Pennings et al. 1996), and the effects of climate change on development (Armstrong et al. 2017; Horwitz et al. 2017), have used Stylocheilus or Bursatella as model organisms. Bursatella has been proposed as a model for neuroscience research (Ramos et al. 1995) and studies on circadian rhythm regulation have been conducted on this species (Block and Roberts 1981). Moreover, Bursatella leachii has drawn attention from the invasion biology community because of its recent spread into the Mediterranean Sea, most likely the result of a natural migration from the Atlantic Ocean (Bazzicalupo et al. 2018; Rizgalla and Crocetta 2020). Finally, species of Bursatella and Stylocheilus are locally abundant and ecologically important epiphytic grazers (Bendell 2006) that play roles in the control of toxic cyanobacterial blooms (Capper et al. 2005; Capper and Paul 2008). Understanding the systematics of Bursatella and Stylocheilus might have considerable implications for many of these other fields of science.

The large geographic ranges of $B$. leachii and $S$. striatus are suggestive of a more complex taxonomy than what is revealed by morphological data. In this paper we examined the systematics of the benthic species of these two genera by using an integrative approach. Molecular phylogenetic and species delimitation analyses were coupled with morphological examination of key characters, and were used to uncover possible cryptic diversity in these two groups.

\section{Methods}

Specimens

To determine whether $B$. leachii and $S$. striatus constitute species complexes, a collection of both museum samples and newly collected specimens was obtained from localities across their global ranges. The samples were all preserved in 70-90\% ethanol; some consisted of full specimens, whereas others were small pieces of tissue cut from either the foot or the mantle of the animal. Surveyed museums include the Invertebrate Zoology Collection of the California Academy of Sciences (CASIZ), the Natural History Museum of Los Angeles County (LACM), and the Museo de Zoología Universidad de Costa Rica (MZUCR). Information on type specimens was obtained from the online databases or curatorial staff in several natural history museums, including the Australian Museum (AM), Natural History Museum of the United Kingdom, London, UK (NHMUK), the Muséum National d'Histoire Naturelle, Paris, France (MNHN), the Senckenberg Natural History Museum, Frankfurt am Main, Germany (SNHM), the Auckland War Memoria Museum, New Zealand (AWMM), the Swedish Museum of Natural History, Stockholm, Sweden (SMNH), the Naturalis Biodiversity Center, Leiden, the Netherlands (NBC), the South African Museum, Cape Town, South 
Africa (SAM), and the United States National Museum, Smithsonian Institution, Washington, DC, USA (USNM). A total of 46 specimens were newly sequenced here, although 19 of them had already been partially sequenced for one gene (cytochrome $c$ oxidase subunit I) during a previous study (Bazzicalupo et al. 2018). Sequences for seven additional specimens were acquired from GenBank. The complete list of specimens with locality data and collection dates is available in Table 1. An additional 120 specimens (not suitable for molecular work) were examined morphologically only (see Systematics section below). The New Caledonian samples have been collected under the permit obtained from the Province Sud of New Caledonia number 2444-2017/ARR/DENV. Additional material was obtained during the Panglao Marine Biodiversity Project (PIs P. Bouchet and D. Largo) of the 'Our Planet Reviewed' expeditions sponsored by the Muséum National d'Histoire Naturelle, Paris.

\section{DNA extraction, amplification, sequencing}

Small tissue samples obtained from foot or mantle of specimens were fragmented using sterile forceps and razor blades. DNA was extracted from specimens using either a Hot Chelex extraction method or a DNeasy Blood and Tissue Kit (Qiagen). The Hot Chelex extraction was conducted as follows. After maceration, the tissue was transferred in $1 \mathrm{~mL}$ of $1 \times$ TE Buffer, contained in a $1.7-\mathrm{mL}$ microcentrifuge tube. To allow the tissue to rehydrate and the cells to lyse, the tube was then placed on a rotating block for at least 20 min. After this time, the tube was vortexed for $5 \mathrm{~s}$ and then centrifuged for $3 \mathrm{~min}$ at $21000 \mathrm{~g}$. Being careful not to disturb the tissue pellet, $975 \mu \mathrm{L}$ of $1 \times$ TE Buffer were removed from the tube, and $175 \mu \mathrm{L}$ of $10 \%$ Chelex solution were then added to the tube. After being vortexed, the tube was put in a $56^{\circ} \mathrm{C}$ hot water bath for at least $20 \mathrm{~min}$. After $5 \mathrm{~s}$ of vortexing, the tube was then put in a $100^{\circ} \mathrm{C}$ heat block for exactly $8 \mathrm{~min}$. Finally, the tube was vortexed and centrifuged for $3 \mathrm{~min}$ at $21000 \mathrm{~g}$. The supernatant resulting from the centrifugation was then used as a template for amplification through Polymerase Chain Reaction (PCR). DNeasy extraction was conducted following the manufacturers' protocol for tissue samples.

Portions of two mitochondrial genes, the cytochrome $c$ oxidase subunit I (COI) gene and the $16 \mathrm{~S}$ rRNA (16S) gene, and a portion of one nuclear gene, the Histone 3 (H3) gene, were amplified by PCR. The following primers were used for amplification of the different genes: for COI, both the universal primers (LCOI490 5'-GGTCAACAAATCATAAAG ATATTGG-3', HCO2198 5'-TAAACTTCAGGGTGACCA AAAAATCA-3') identified by Folmer et al. (1994), and specific primers designed for $B$. leachii (forward $5^{\prime}$-GGGA TGTGATGTGGTCTAGTAGGAAC-3', reverse $5^{\prime}$-ATAGGA TCTCCTCCTCCCGCAGGATC-3'); for $16 \mathrm{~S}$, the universal primers (16S ar-L 5'-CGCCTGTTTATCAAAAACAT-3', $16 \mathrm{~S}$ br-H 5'-CCGGTCTGAACTCAGATCACGT-3') developed by Palumbi (1996); and for $H 3$, the universal primers $(H 3$ AF 5'-ATGGCTCGTACCAAGCAGACGGC-3', H3 AR 5'-ATATCCTTGGGCATGATGGTGAC- $3^{\prime}$ ) developed by
Colgan et al. (2000). Each reaction tube contained a total of $50 \mu \mathrm{L}$ of reaction mixture, which included: $0.25 \mu \mathrm{L}$ of 5 units $\mu \mathrm{L}^{-1}$ of Taq polymerase, $5.00 \mu \mathrm{L}$ of $10 \times$ PCR buffer, $5.00 \mu \mathrm{L}$ of $25 \mathrm{mM} \mathrm{MgCl}, 1.00 \mu \mathrm{L}$ of $40 \mathrm{mM}$ dNTPs, $1.00 \mu \mathrm{L}$ of each $10-\mathrm{mM}$ primer, $34.75 \mu \mathrm{L}$ of $\mathrm{H}_{2} \mathrm{O}$, and $2.00 \mu \mathrm{L}$ of template DNA. For the amplification of $\mathrm{COI}$, the thermocycler was set as follows: $3 \mathrm{~min}$ at $95^{\circ} \mathrm{C}$ for an initial denaturation of the DNA; 35 cycles of denaturation at $94^{\circ} \mathrm{C}$ for $45 \mathrm{~s}$, annealing at $45^{\circ} \mathrm{C}$ for $45 \mathrm{~s}$ and elongation at $72^{\circ} \mathrm{C}$ for $90 \mathrm{~s}$; a final elongation step of $10 \mathrm{~min}$ at $72^{\circ} \mathrm{C}$. For the amplification of $16 \mathrm{~S}$ and $\mathrm{H3}$ the thermocycler was set as follows: $3 \mathrm{~min}$ at $95^{\circ} \mathrm{C}$ for an initial denaturation of the DNA; 30 cycles of denaturation at $94^{\circ} \mathrm{C}$ for $30 \mathrm{~s}$, annealing at $50^{\circ} \mathrm{C}$ for $30 \mathrm{~s}$ and elongation at $68^{\circ} \mathrm{C}$ for $60 \mathrm{~s}$; a final elongation step of $7 \mathrm{~min}$ at $68^{\circ} \mathrm{C}$

A $1 \%$ agarose gel stained with ethidium bromide was then prepared to run a gel electrophoresis of the PCR products, in order to verify the presence of DNA fragments. PCR products that showed appropriate size fragments were then purified using the GeneJET PCR Purification Kit by Thermo Scientific, following the manufacturers' protocol. Concentrations of the purified DNA fragments were then checked using a NanoDrop 1000 spectrophotometer (Thermo Scientific) and sent to Sequencing to Source Bioscience Inc. (Santa Fe Springs, CA, USA) company, which performed Sanger sequencing of the fragments. Assemblage and editing of the sequences was done with the software GENEIOUS PRO (ver. 4.7.4, Biomatters Ltd). Consensus sequences were aligned and concatenated for the following analyses using the same software.

\section{Phylogenetic analyses}

Sequences newly obtained through PCR amplification, plus additional sequences obtained either from GenBank or from Bazzicalupo et al. (2018), were used for the phylogenetic analyses (see Table 1). Akera bullata O. F. Müller, 1776 was selected as the outgroup based on its sister relationship with the rest of the Aplysiida. The species Aplysia californica J. G. Cooper, 1863, Notarchus indicus Schweigger, 1820 and Petalifera ramosa Baba, 1959 were included in the analyses for comparison, based on the phylogeny by Medina and Walsh (2000), which placed Aplysia and Notarchus as basal sea hare taxa, and Petalifera as sister to Bursatella and Stylocheilus. The best-fit models of evolution for the three genes (GTR+I for $16 \mathrm{~S}$, $\mathrm{GTR}+\mathrm{I}+\mathrm{G}$ for the entire $\mathrm{COI}$ gene, $\mathrm{SYM}+\mathrm{I}$ for $\mathrm{COI}$ codon position $1, \mathrm{HKY}$ for $\mathrm{COI}$ codon position $2, \mathrm{GTR}+\mathrm{G}$ for $\mathrm{COI}$ codon position 3, GTR $+\mathrm{G}$ for the entire $\mathrm{H3}$ gene, GTR for $\mathrm{H3}$ codon position 1, JC for $H 3$ codon position 2, HKY for $H 3$ codon position 3 , and $\mathrm{GTR}+\mathrm{I}+\mathrm{G}$ for the entire concatenated dataset) were determined with the Akaike information criterion, using the software JModelTest (ver. 2.1.10, see https:/github.com/ ddarriba/jmodeltest2; Darriba et al. 2012). Both Bayesian and Maximum Likelihood based trees were constructed for the study. The analyses were conducted for the entire concatenated alignment of all three genes, and for the single genes individually. Bayesian analyses were performed using the software MrBayes (ver. 3.2.6, see http://nbisweden.github.io/ MrBayes/index.html; Ronquist et al. 2012), partitioned by gene and codon position (unlinked). The Markov chain Monte Carlo 


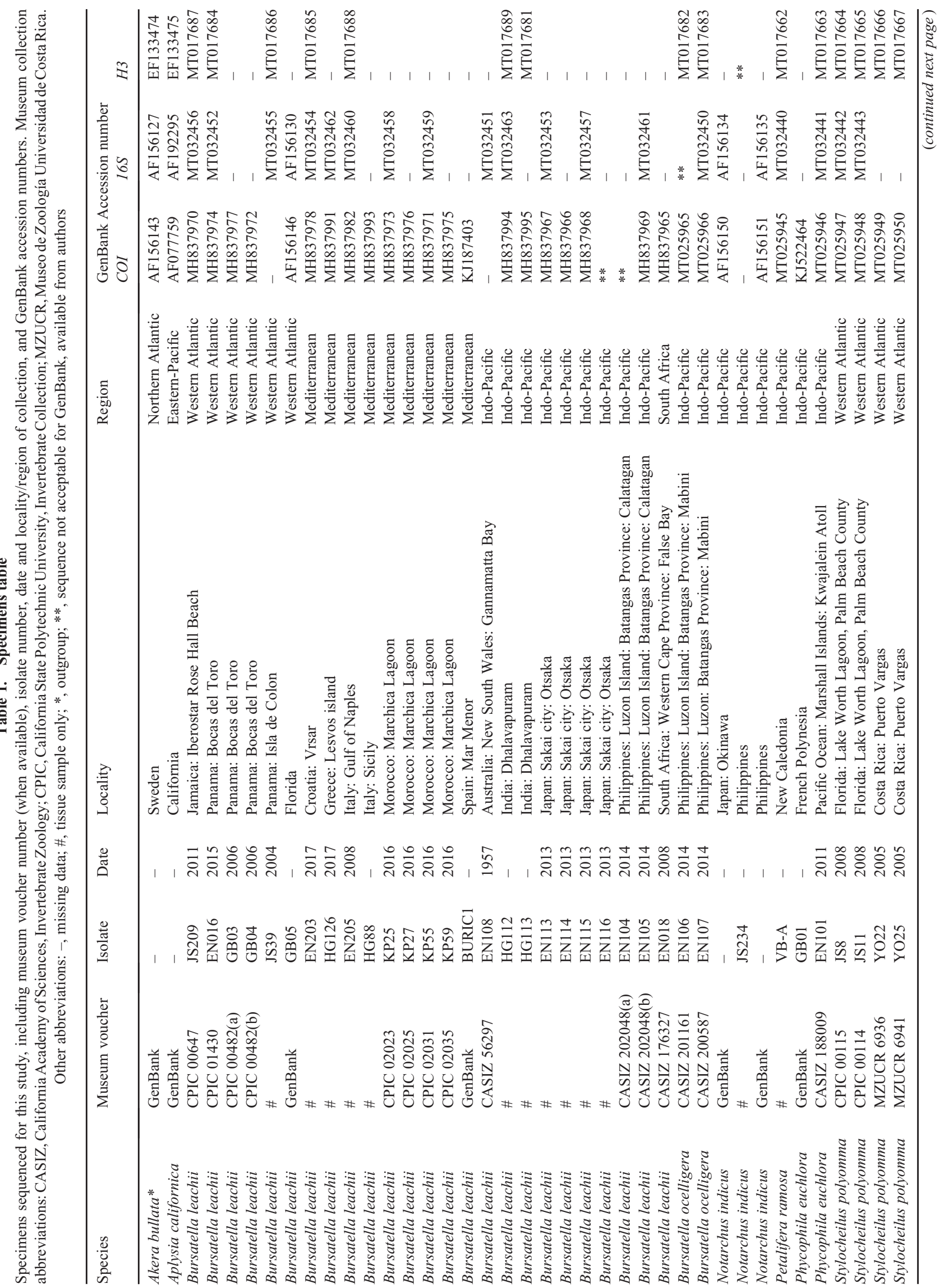




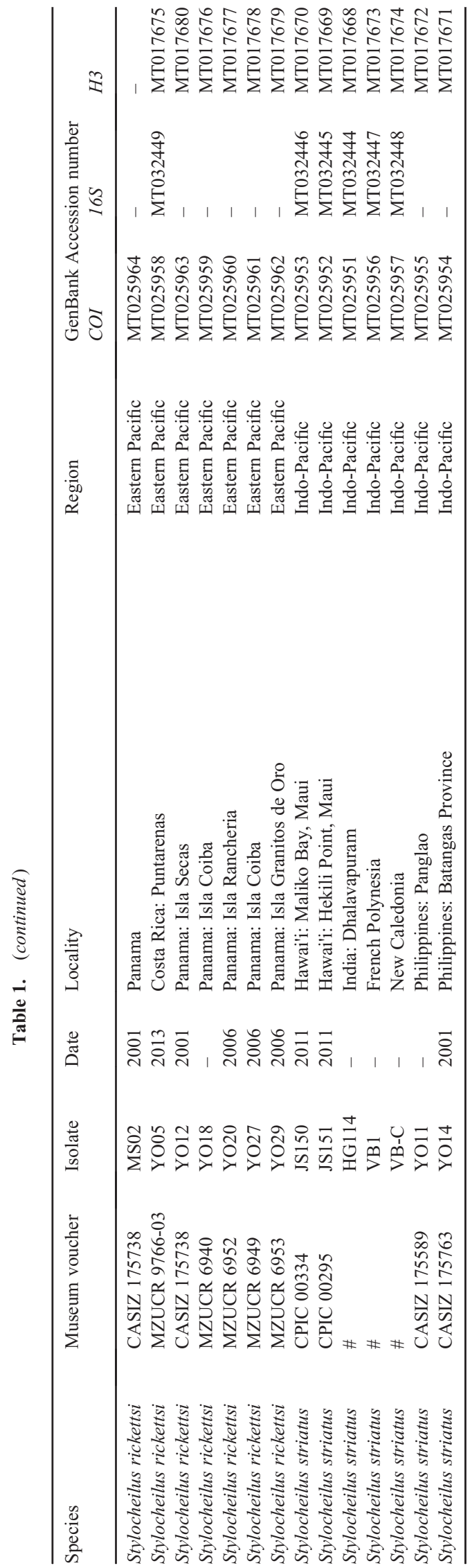

analysis was executed with two runs of six chains for 10 million generations, with sampling every 100 generations. Maximum likelihood analyses were performed using the software raxmlGUI (ver. 1.5, see https://antonellilab.github.io/ raxmlGUI/; Silvestro and Michalak 2012), selecting the bootstrap+consensus option, with 10000 replicates.

\section{Species delimitation analyses}

The phylogenetic tree results were used to run the Bayesian implementation of the Poisson tree processes (bPTP) (Zhang et al. 2013). This analysis implements a Markov chain Monte Carlo sampler to the original Poisson tree processes model (Zhang et al. 2013). It divides the samples into hypothetical species and assigns likelihood scores to each hypothetical species group. Groups with a likelihood score of $<0.5$ are discarded. The analysis was run on the concatenated Bayesian tree results, using one million MCMC generations, with sampling every 100 generations and $20 \%$ burn-in.

An Automatic Barcode Gap Discovery (ABGD) analysis was performed to further corroborate the species status of the clades identified through the phylogenetic and bPTP analyses. The COI gene sequence alignment was uploaded on the ABGD web tool (http://wwwabi.snv.jussieu.fr/public/abgd/abgdweb. $\mathrm{html}$ ), and the analysis was performed twice, once using the Jukes-Cantor (JC69) model and once using the Kimura (K80) model to calculate pairwise distances, as implemented by the software. The default relative gap width (x) of 1.5 and a range of prior values for maximum divergence of intraspecific diversity (P) from 0.001 to 0.1 were used for the analysis.

The analysis was run separately for Stylocheilus and Bursatella specimens to obtain higher resolution of the possible barcoding gaps within each genus.

\section{Morphology}

Based on the study by Eales and Engel (1935) and more modern approaches to the systematics of sea hares (Valdés et al. 2017; Cunha and Simone 2019), several taxonomically informative anatomical structures were examined to highlight morphological differences between species. At least two representative specimens (when available) for each species identified by molecular data were examined morphologically, and their radula, jaws, gizzard plates, and copulatory organs were illustrated. With the aid of a Nikon SMZ100 dissecting microscope, a dorsal incision of the anterior part of the animal was performed. From that opening, the anterior distal part of the digestive tract, which comprises the buccal mass, the oesophagus, the crop, and the gizzard, was removed and placed in a $10 \%$ sodium hydroxide solution. Once the tissue was softened by the solution, the radula and jaws were extracted from the buccal mass, rinsed in water, and mounted on a stub. The gizzard plates were extracted by opening the softened gizzard, submerged in ethanol $99 \%$ for $3 \mathrm{~min}$ and then placed in $2 \mathrm{~mL}$ of hexamethyldisilazane until all the liquid evaporated, leaving the gizzard plates hardened, so that they could be mounted on a stub. The male reproductive organ was dissected from the same opening as the distal part of the digestive tract. After being submerged in $70 \%$ ethanol, it was photographed under a Leica EZ4D microscope with a 
built-in digital camera. By cutting open the penial sheath with a careful incision, the penis was dissected, submerged in $99 \%$ ethanol for $3 \mathrm{~min}$ and then placed in $2 \mathrm{~mL}$ of hexamethyldisilazane until all of the liquid had evaporated. Once hardened, it could be mounted on a stub as well. All the structures mounted on the stubs were then sputter coated for examination under a Jeol JSM-6010 variable-pressure scanning electron microscope. One of the specimens (collection code: CASIZ-188009, isolate: EN101) possessed an internal shell, which was photographed with the Leica EZ4D microscope and the scanning electron microscope.

\section{Results}

The Bayesian and Maximum Likelihood analyses of the concatenated alignment $(\mathrm{COI}, 16 \mathrm{~S}, \mathrm{H3})$ produced trees with identical overall topologies (Fig. 1). The specimens form a total of six well-supported terminal clades, as indicated by the fairly high values of posterior probability (pp) and maximum likelihood bootstrap ( $\mathrm{mlb}$ ).

Two distinct clades were recovered for Bursatella. The first clade (Clade I in Fig. 1), comprises specimens with a nearly pantropical distributional range (pp: 1, mlb: 100). This clade includes specimens from the Atlantic Ocean (Florida, Jamaica, Panama), the Mediterranean Sea (Croatia, Greece, Italy, Morocco, Spain), the southern tip of South Africa, and the Indo-Pacific Ocean (Australia, India, Japan, Philippines). The second clade (Clade II in Fig. 1) (pp: 1, mlb: 100), comprises two specimens from the Philippines.

Three distinct clades were recovered for Stylocheilus. The first clade (Clade III in Fig. 1), comprises specimens from the Atlantic Ocean (pp: 0.99, mlb: 89), including Florida and the Atlantic coast of Costa Rica. The second clade (Clade IV in Fig. 1) includes Indo-Pacific specimens (pp: 1, mlb: 81) collected in Hawai'i, India, Philippines, French Polynesia and New Caledonia. Recovered as sister to Clade IV, although this relationship shows low support (pp: 0.82, mlb: 50), Clade V comprises specimens from the Eastern Pacific (pp: 1, mlb: 100), from Pacific coasts of Panama and Costa Rica.

Two specimens from the Pacific Ocean, one from the Marshall Islands previously identified as B. leachii and a sequence from GenBank from French Polynesia identified as Stylocheilus, were recovered as a clade (Clade VI in Fig. 1) distinct from both Bursatella and Stylocheilus clades (pp: 1, mlb: $100)$ and sister to the latter.

Trees generated with individual gene alignments show similar topology, with a few notable differences (Fig. S1 of the Supplementary material). For example, in the COI analysis, the Atlantic and Eastern Pacific clades of Stylocheilus are recovered as sister taxa, instead of the latter being sister to the Indo-Pacific clade. In the $16 S$ analysis, all the Stylocheilus specimens are grouped into a single clade. In the $H 3$ analysis, the Atlantic Stylocheilus clade loses support, whereas IndoPacific and Eastern Pacific Stylocheilus are recovered as a single clade. These differences are most likely due to substitution rates varying between genes.

The groups identified by the bPTP analysis were congruent with the clades revealed by the phylogenetic analysis, with likelihood scores all $\geq 0.6$ (Fig. S2 of the Supplementary material). In both repetitions of the ABGD analysis, histograms of frequencies of pair-wise distance values, calculated with the JC69 and the K80 models, show clear barcoding gaps between the highest intraspecific distance and the lowest interspecific distance (Fig. S3 of the Supplementary material). The results of the analysis, run with the Stylocheilusonly and Bursatella-only datasets, confirm three distinct Stylocheilus groups and two distinct Bursatella groups, identified by the ABGD partition for values of $\mathrm{P}$ of up to 0.0129 and 0.1 respectively.

The examination of the internal anatomy of representative specimens from all geographic regions unveiled consistent differences in morphological features (described below in the Systematics section) between the clades recovered in the phylogenetic analyses as well as the candidate species identified in the species delimitation analysis, further confirming their status as distinct species. These diagnostic traits, together with the locality of the original description of specimens of different geographic areas, have been used to assign names resurrected from synonymy to the different candidate species. The names were assigned as such: Bursatella leachii for Clade I, the pantropical Bursatella species; Bursatella ocelligera for Clade II, the Bursatella species from the Indo-Pacific; Stylocheilus polyomma for Clade III, the Stylocheilus species from the Atlantic; Stylocheilus striatus for Clade IV, the Stylocheilus species from the Indo-Pacific; Stylocheilus rickettsi for Clade V, the Stylocheilus species from the Eastern Pacific; and Phycophila euchlora for Clade VI. Details regarding the process of assigning these names, together with an extensive literature review of the systematics of each genus and species, are discussed in the Systematics section (see below).

\section{Systematics}

Genus Bursatella de Blainville, 1817

Bursatella de Blainville, 1817: 138.

Type species: Bursatella leachii de Blainville, 1817, by monotypy.

Aclesia Rang, 1828: 68.

Type species: Aplysia pleii Rang, 1828, by subsequent designation by Gray (1847).

Ramosaclesia Iredale, 1929: 352.

Type species: Aclesia glauca Cheeseman 1878, by monotypy.

?Barnardaclesia Eales \& Engel, 1935: 282.

Type species: Aplysia cirrhifera Quoy \& Gaimard, 1832, by original designation.

\section{Diagnosis}

Body oval, soft, with broad and short, triangular posterior end of foot (metapodium). Body surface, rhinophores, and oral tentacles covered with numerous elongate primary papillae of 


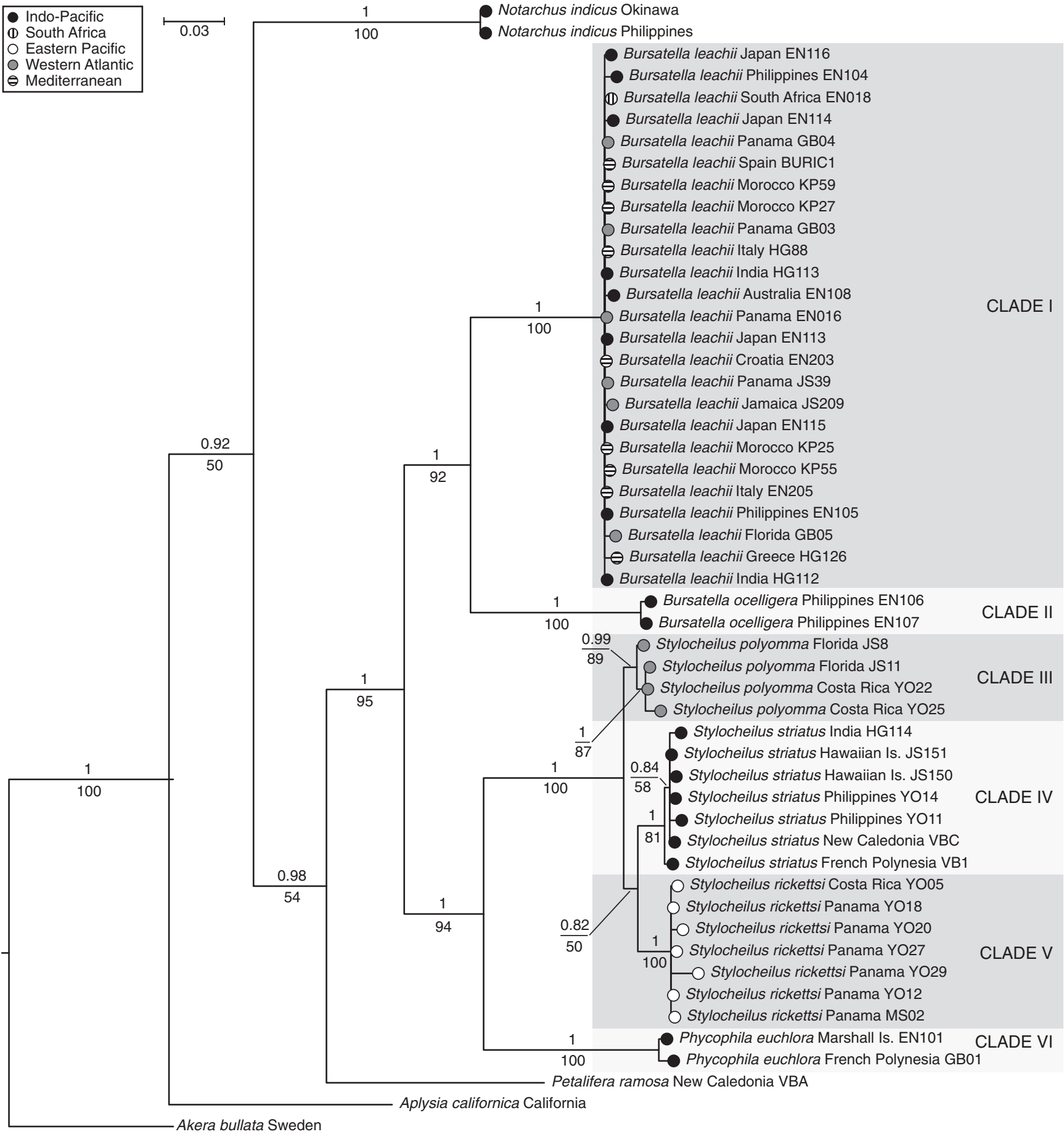

Fig. 1. Bayesian consensus tree $(C O I+16 S+H 3)$ for 27 specimens of Bursatella, 18 specimens of Stylocheilus, two specimens of Phycophila, and the outgroup taxa, including posterior probabilities (above nodes) and bootstrap support values from the maximum-likelihood analysis (below nodes). The geographical region of origin for all specimens is colour coded, and the specific geographical origin and isolate number are indicated for each specimen (see Table 1).

variable length, sometimes with secondary branches. Mantle cavity with reduced opening, containing large gill, surrounded or covered by short parapodia. Shell absent. Radula with broad rachidian teeth and numerous denticulate lateral teeth. Penis armed with numerous spines or unarmed; internal surface of the penial canal unarmed.

\section{Remarks}

De Blainville (1817) described the genus Bursatella based on the single species Bursatella leachii de Blainville, 1817, as lacking a shell and having an almost globular body, with a dorsal oval cavity edged by thick, almost symmetrical margins 
(parapodia), and ornamented with four ramified tentacles, two buccal appendages, and dorsal tentacles (=rhinophores) on the head. Eales and Engel (1935) provided additional details and illustrations of the type species and established the modern usage of the name.

Rang (1828) treated most Aplysiidae as members of the genus Aplysia, and used subgenera to classify and distinguish among groups with distinct morphological characteristics. However, Rang (1828) retained Bursatella as a distinct genus from Aplysia for Bursatella leachii, mainly because he was unclear about the characteristics of this animal and because he wanted to draw attention to this remarkable species. At the same time, Rang (1828) introduced the subgenus Aclesia in the plates of his monograph for several species currently considered to be members of Bursatella and Stylocheilus. But in the text, which was completed later, Rang (1828) indicated that he was mistaken introducing the subgenus Aclesia because those species belong to Notarchus Cuvier, 1816. Pilsbry $(1895,1896)$ and O'Donoghue (1929) indicated that Bursatella savigniana Audouin, 1826 was the type species of Aclesia, but earlier Gray (1847) had selected Aplysia pleii Rang, 1828 as the type species. Because $A$. pleii is a synonym of $B$. leachii, Aclesia is a synonym of Bursatella.

Iredale (1929), in a brief note, indicated that the species Aclesia glauca Cheeseman, 1878, described from New Zealand, does not belong to Notarchus (to which it was previously transferred) and suggested to use it under its original binomen or 'better still' under the new subgenus Ramosaclesia. Because Aclesia glauca is a synonym of B. leachii (see Eales and Engel 1935), Ramosaclesia is a synonym of Bursatella.

Eales and Engel (1935) introduced the new genus name Barnardaclesia for Aplysia cirrhifera Quoy \& Gaimard, 1832. Eales and Engel (1935) considered Barnardaclesia as distinct from Bursatella and Stylocheilus because of several morphological differences between $A$. cirrhifera and other species of Notarchidae. For example, Eales and Engel (1935) noted that $A$. cirrhifera was larger than species of Stylocheilus but smaller than species of Bursatella, and had a long, slender posterior end of the foot (metapodium), as in Stylocheilus. Quoy and Gaimard (1832) indicated that the length of the specimens of $A$. cirrhifera they examined was ' 3 pounces' [=three French inches], which is $~ 81 \mathrm{~mm}$; Rudman (1999) reported a maximum size of $65 \mathrm{~mm}$ for Stylocheilus striatus, whereas Bursatella leachii can reach up to $150 \mathrm{~mm}$ in length (Gosliner et al. 2018). According to Eales and Engel (1935), differences between A. cirrhifera and species of Stylocheilus included the 'absence of spines in the preputium' [=penial canal] and having the 'hermaphrodite opening just inside the mantle cavity' rather than just outside as in Stylocheilus. However, Rudman (2006) noted that Bursatella also has the hermaphrodite opening just inside the mantle cavity. Several authors considered Barnardaclesia to be a synonym of Bursatella (see Macnae 1962; Marcus 1972) whereas others maintained it as a distinct genus (Bebbington 1969, 1974). Pruvot-Fol (1934) examined one of the syntypes of A. cirrhifera and provided illustrations of the radula and penial spines, which are similar to those of specimens of
Bursatella here examined. Eales (1952) provided a detailed description of $A$. cirrhifera based on newly collected material from St Lucia, KwaZulu-Nataland, South Africa, and illustrated details of the anatomy. The live animals examined by Eales (1952) were $90 \mathrm{~mm}$ in length, drab grey with elliptical yellow spots, often with a more intensely coloured centre, bordered with a narrow, darkly pigmented area, which fit within the known variability of $B$. leachii. Also, the internal anatomy seems consistent with that of $B$. leachii. Owing to lack of illustrations of the live animals, it is unclear whether the specimens examined by Eales (1952) match the original description of $A$. cirrhifera. Because we do not have access to newly collected specimens similar to the original description of A. cirrhifera, and because of the apparent lack of distinctive characters between Barnardaclesia and Bursatella, we are unable to justify the maintenance of Barnardaclesia as a distinct genus. Consequently, we follow the most conservative opinion and maintain Barnardaclesia as a synonym of Bursatella until new evidence becomes available.

Eales and Engel (1935) provided a comprehensive review of the taxonomic history of Bursatella, established its synonymy, and concluded that this genus contains a single, pantropical species: Bursatella leachii. Although Eales and Engel (1935) considered that other described species of Bursatella were synonyms of $B$. leachii, they recognised the existence of geographic variants and developed a subspecies scheme to classify the morphological diversity of this species. This opinion is widely accepted and the subspecies scheme remains in place (Bebbington 1969, 1974, 1977; Marcus 1972). In this study, we have found that molecular results do not agree with the current subspecies classification scheme and therefore a new taxonomy is proposed below.

Bursatella leachii de Blainville, 1817

(Fig. 2A, B, 3-6)

Bursatella leachii de Blainville, 1817: 138.

Type locality: Indian Seas.

Bursatella savigniana Audouin, 1826: 17-18, pl. 2, fig. 2.1-2.13.

Type locality: Egypt (Red Sea).

Aplysia pleii Rang, 1828: 70, pl. 21, fig. 2-4.

Type locality: Antilles.

Notarchus laciniatus Rüppell \& Leuckart, 1828-30 [1830]: 24-25, pl. 7, fig. $2 \mathrm{a}-\mathrm{c}$.

Type locality: El Tor, Egypt (Red Sea).

?Aplysia cirrhifera Quoy \& Gaimard, 1832: 311-312, pl. 24, fig. 8.

Type locality: 'aux Cerfs de l'Ile-de-France' [=Île aux Cerfs], Mauritius.

Bursatella lacinulata Couthouy - in Gould, 1852: 223-224, pl. 16, fig. 269, 269a. 
Type locality: Rio de Janeiro, Brazil.

Notarchus cirrosus Stimpson, 1855: 378.

Type locality: China.

Aclesia glauca Cheeseman, 1878: 277, pl. 15, fig. 4.

Type locality: Auckland Harbour, New Zealand.

Notarchus intrapictus Cockerell, 1893: 218-220.

Type locality: Kingston, Jamaica.

Notarchus brevipes Hägg, 1904: 1-5, pl. 1, fig. 1-3.
Type locality: El Tor, Egypt (Red Sea).

Aclesia freeri Griffin, 1912: 65-90, text fig. 1-5, pls 1-6.

Type locality: Manila Bay, Philippines.

Aclesia africana Engel, 1926: 100-104, fig. 11-14.

Type locality: 'Knijsna' [=Knysna], South Africa.

Aclesia rosea Engel, 1926: 104-105, fig. 15-16.

Type locality: 'Baie de l'Ouest' [=west side of Ras Nouadhibou], Western Sahara.

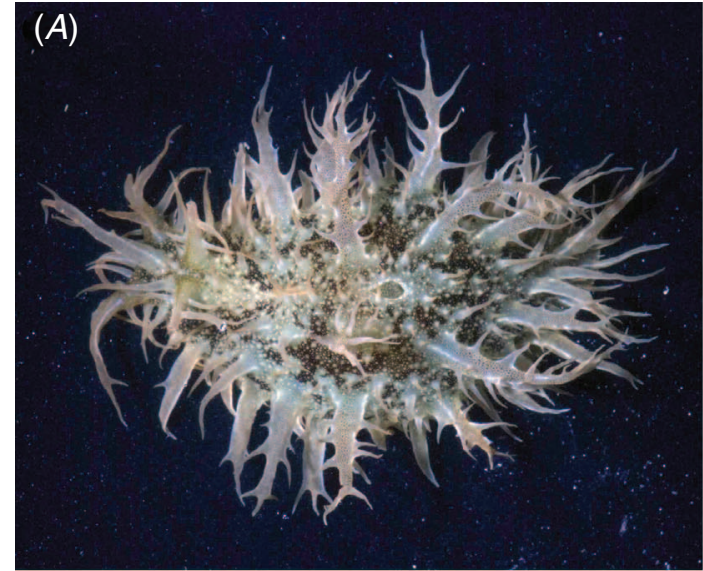

(C)
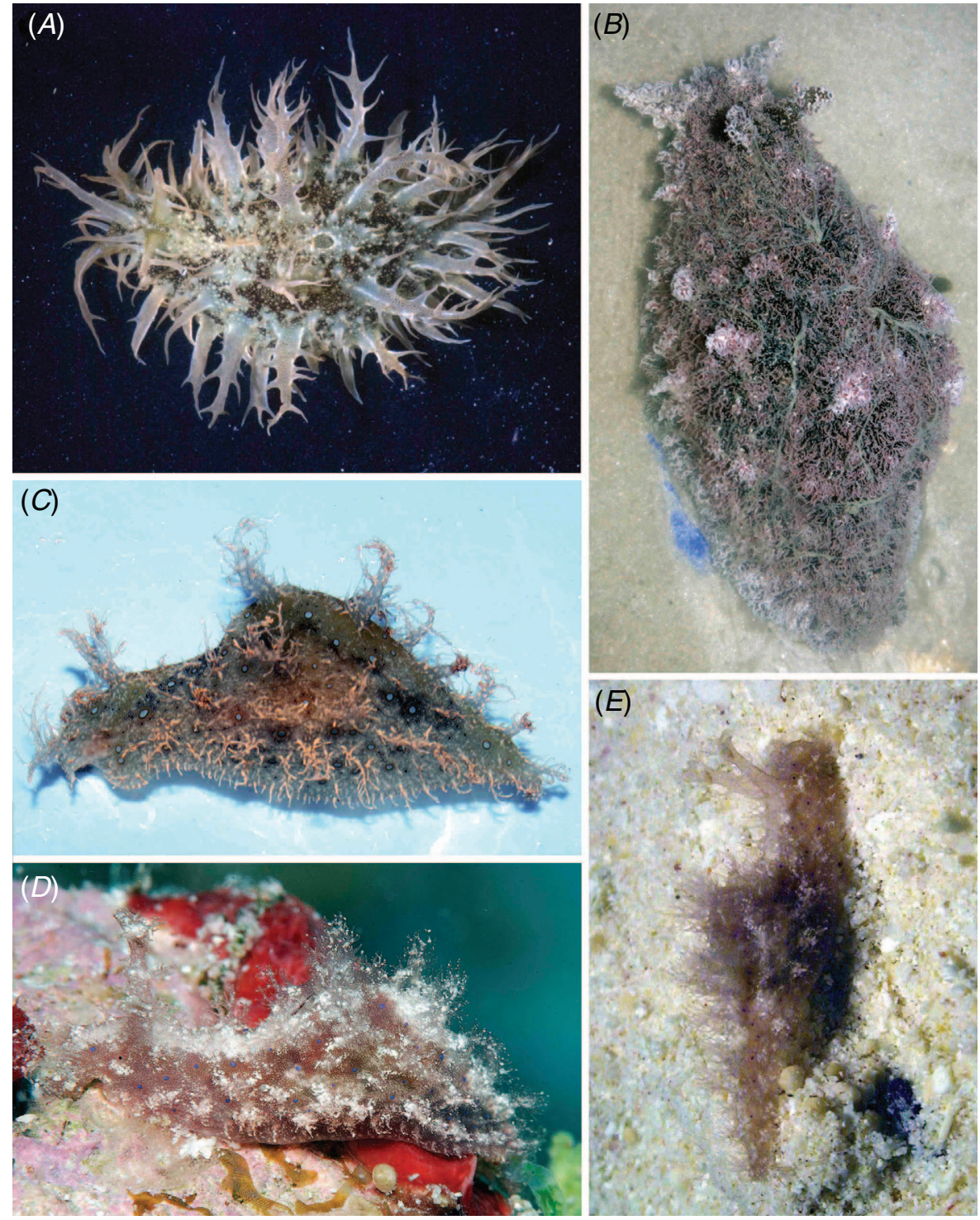

Fig. 2. Photographs of live animals. A, Bursatella leachii de Blainville, 1817, specimen from Bocas del Toro, Panama (CPIC 01430) (EN016). B, Bursatella leachii de Blainville, 1817, specimen from Simon's Bay, South Africa (CASIZ 176327) (EN018). C, Bursatella ocelligera (Bergh, 1902), specimen from Batangas, Philippines (CASIZ 200587) (EN107). D, E, Phycophila euchlora Adams, 1861, specimen from Kwajalein Atoll, Marshall Islands (CASIZ 188009) (EN101). 
?Notarchus villosus O’Donoghue, 1929: 25-30, pl. 3, fig. 27-32.

Type locality: Algoa Bay, South Africa.

?Ramosaclesia rex Allan, 1932: 317-319, pl. 35, fig. 1-6.

Type locality: Manly Lagoon, Queenscliff, near Sydney, Australia.
Bursatella leachii hirasei Eales \& Engel, 1935: 298 [Hirase 1934, p. 93, pl. 120, fig. 16].

Type locality: Japan.

Bursatella leachii guineensis Bebbington, 1969: 323-340, fig. 1-15.

Type locality: Tema Harbour, Ghana.
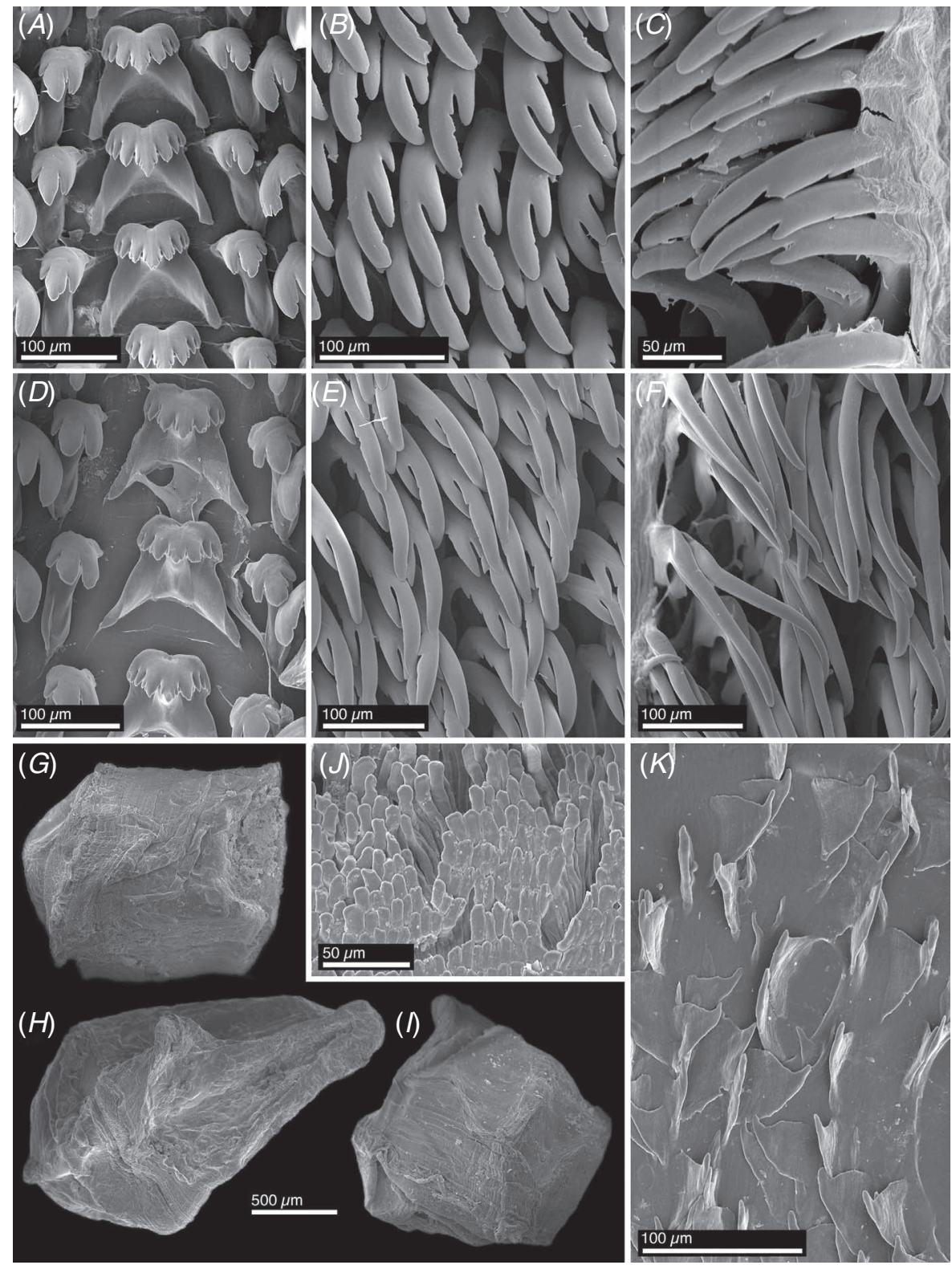

Fig. 3. Scanning electron micrographs of the anatomy of Bursatella leachii de Blainville, 1817, specimens from the Mediterranean. $A-C$, Radular teeth of a specimen from Murcia, Spain (CPIC 02040) (EN207): rachidian and inner lateral teeth $(A)$, mid-lateral teeth $(B)$, outer lateral teeth $(C)$. $D-F$, Radular teeth of a specimen from Murcia, Spain (CPIC 002043) (EN210): rachidian and inner lateral teeth $(D)$, mid-lateral teeth $(E)$, outer lateral teeth $(F)$. $G-I$, Gizzard plates of specimens from Murcia, Spain: $H, I$ (CPIC 02040) (EN207); $G$ (CPIC 002043) (EN210). $J$, Jaw elements of a specimen from Murcia, Spain (CPIC 002043) (EN210). $K$, Postradular armature of a specimen from Murcia, Spain (CPIC 02040) (EN207). 

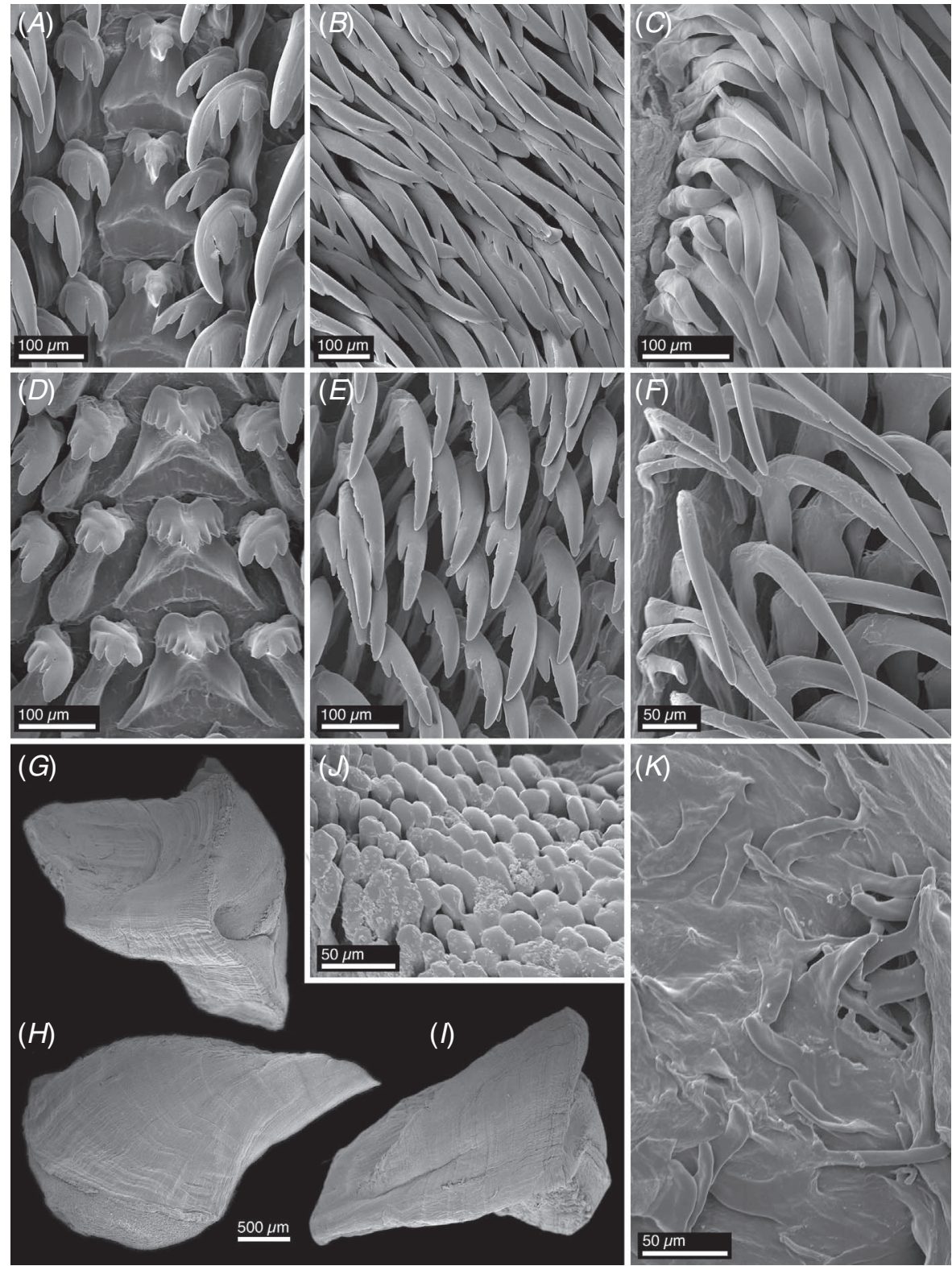

Fig. 4. Scanning electron micrographs of the anatomy of Bursatella leachii de Blainville, 1817, specimens from the Indo-Pacific. $A-C$, Radular teeth of a specimen from Colaba, Mumbai, India (CASIZ 082129) (EN111): rachidian and inner lateral teeth $(A)$, mid-lateral teeth $(B)$, outer lateral teeth $(C) . D-F$, Radular teeth of a specimen from Simon's Bay, South Africa (CASIZ 176327) (EN018): rachidian and inner lateral teeth $(D)$, mid-lateral teeth $(E)$, outer lateral teeth $(F)$. $G-I$, Gizzard plates of specimens from Colaba, Mumbai, India (CASIZ 082129) (EN111). $J$, Jaw elements of a specimen from Colaba, Mumbai, India (CASIZ 082129) (EN111). K, Postradular armature of a specimen from Simon's Bay, South Africa (CASIZ 176327) (EN018)

\section{Type material}

Bursatella leachii de Blainville, 1817, holotype (NHMUK 20100345), not examined. Bursatella savigniana Audouin, 1826, untraceable, not at MNHN (Valdés and Héros 1998). Aplysia pleii Rang, 1828, 1 syntype (MNHN). Notarchus laciniatus Rüppell \& Leuckart, 1830, location unknown, not at SNHM. Aplysia cirrhifera Quoy \& Gaimard, 1832, 2 syntypes
(MNHN). Bursatella lacinulata Couthouy in Gould, 1852, location unknown, not in Johnson (1964). Notarchus cirrosus Stimpson, 1855, most likely destroyed (Dance 1966). Aclesia glauca Cheeseman, 1878, 1 syntype (AWMM MA70004), not examined. Notarchus intrapictus Cockerell, 1893, location unknown. Notarchus brevipes Hägg, 1904, 1 syntype (SMNH 8937), not examined. Aclesia freeri Griffin, 1912, location unknown. Aclesia africana Engel, 1926, 1 syntype (NBC 

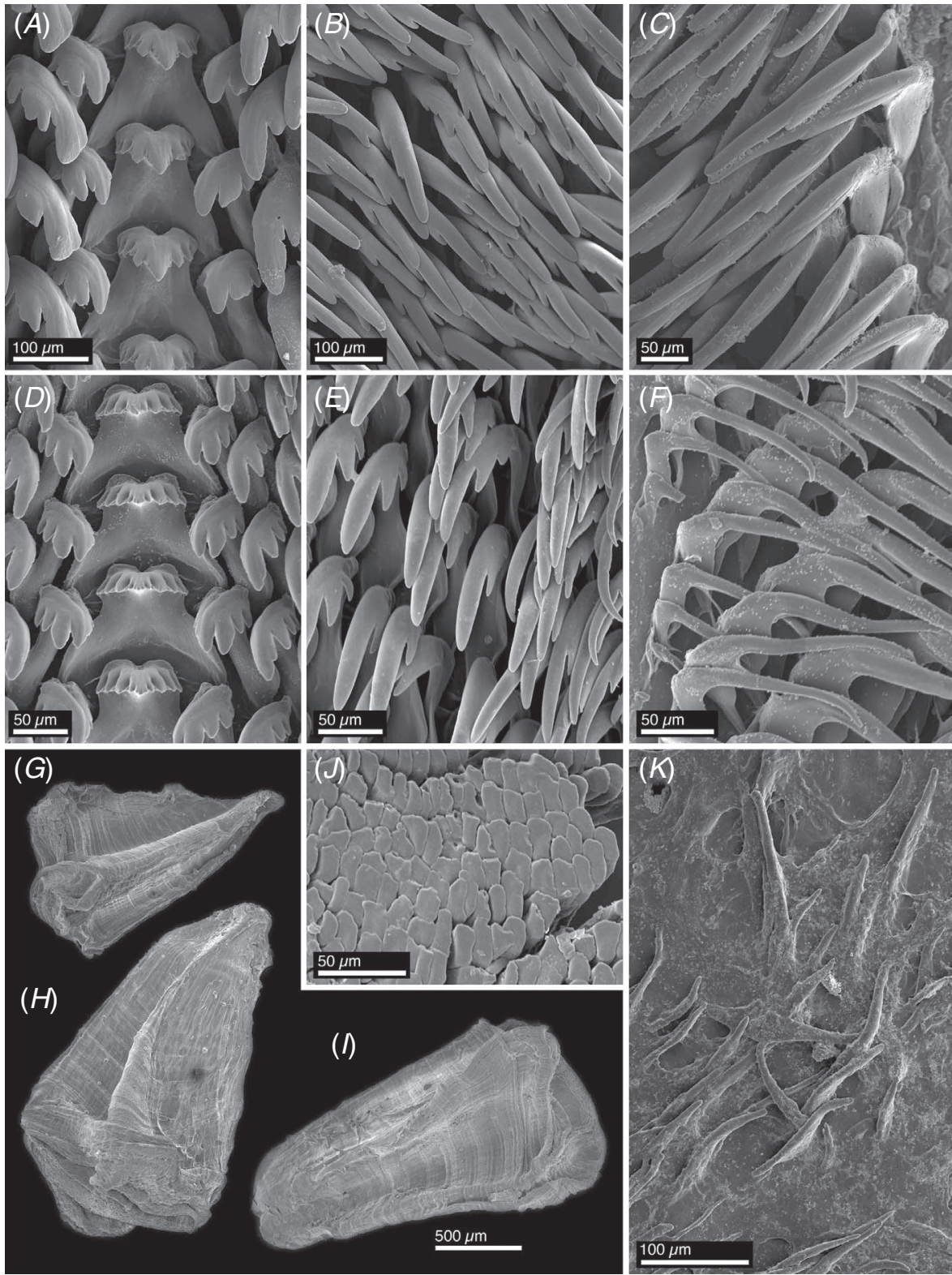

Fig. 5. Scanning electron micrographs of the anatomy of Bursatella leachii de Blainville, 1817, specimens from the western Atlantic. $A-C$, Radular teeth of a specimen from Nueva Esparta, Venezuela (LACM1939198.3): rachidian and inner lateral teeth $(A)$, mid-lateral teeth $(B)$, outer lateral teeth $(C)$. $D-F$, Radular teeth of a specimen from Bocas del Toro, Panama (LACM2004-10.3): rachidian and inner lateral teeth $(D)$, midlateral teeth $(E)$, outer lateral teeth $(F)$. $G-I$, Gizzard plates of specimens from Bocas del Toro, Panama (LACM2004-10.3). $J$, Jaw elements of a specimen from Nueva Esparta, Venezuela (LACM1939-198.3). $K$, Postradular armature of a specimen from Nueva Esparta, Venezuela (LACM1939-198.3).

ZMA-Moll.137570), not examined. Aclesia rosea Engel, 1926, holotype (NBC ZMA-Moll.137576), not examined. Notarchus villosus O'Donoghue, 1929, location unknown, not at SAM (A. Bosman, pers. comm.). Ramosaclesia rex Allan, 1932, holotype (AM C.57495), not examined. Bursatella leachii hirasei Eales \& Engel, 1935, untraceable. Bursatella leachii guineensis Bebbington, 1969, holotype (NHMUK 196839.W), not examined.

\section{Material examined}

CARIBBEAN AND GULF OF MEXICO: Long Boat Key, Florida, 10. xi.2005, 1 specimen 55-mm preserved length (CPIC 00601). STRI Marine Station, Bocas del Toro, 21.ii.2004, 1 specimen 40-mm preserved length (LACM 2004-10.3); 27.viii.2006, 2 specimens 37-mm preserved length (CPIC 00482); 5.viii.2015, tissue sample from 1 specimen (CPIC 01430). Bahía Caledonia, Provincia Colón, Panama, 3.iv.1939, 1 specimen 78-mm preserved length (LACM 1939-174.1). Isla Cubagua, Nueva Esparta, 


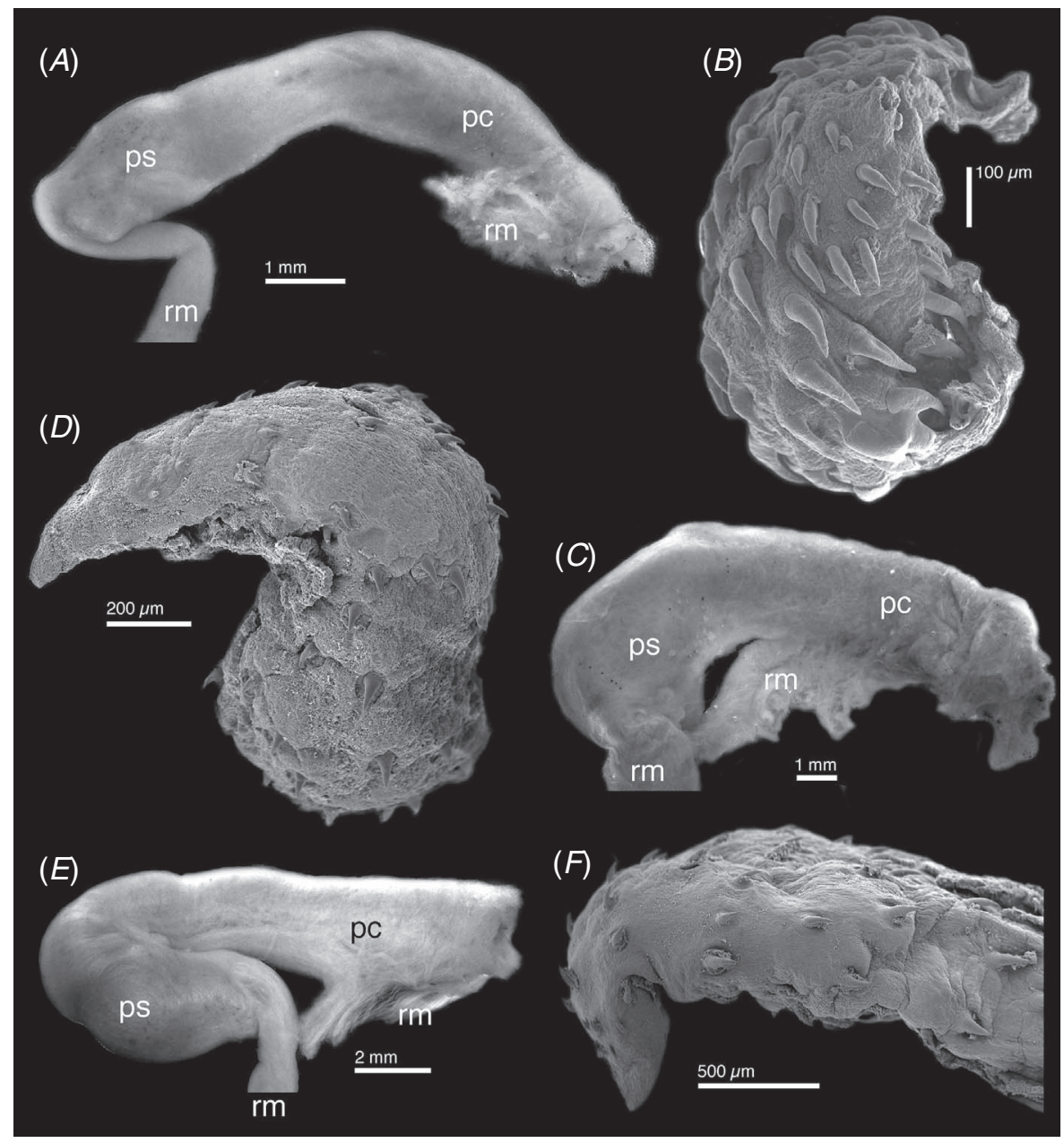

Fig. 6. Penial anatomy of Bursatella leachii de Blainville, 1817. A, B, Specimens from Murcia, Spain (CPIC 02041-02042) (EN209, EN208): complete male reproductive organs ( $A$ ), penis $(B)$. $C, D$, Specimen from Simon's Bay, South Africa (CASIZ 176327) (EN018): complete male reproductive organs $(C)$, penis (D). E, $F$, Specimen from Bahía Caledonia, Panama (LACM 1939-174.1): complete male reproductive organs $(E)$, penis $(F)$. Abbreviations: rm, retractor muscle; pc, penial canal; ps, penial sheath.

Venezuela, 15.iv.1939, 6 specimens 58-85-mm preserved length (LACM 1939-198.3). Bahía Salinas, Falcon, Venezuela, 29.iii.1990, 1 specimen 45-mm preserved length (LACM 1990-47.10).

MEDITERRANEAN: Lago di Faro, Sicily, Italy, 6.vi.2012, 1 specimen 49-mm preserved length (CPIC 02039). San Pedro del Pinatar, Murcia, Spain, 26.viii.2009, 1 specimen 19-mm preserved length (CPIC 02043); 1 specimen 42-mm preserved length (CPIC 02041); 1 specimen 39-mm preserved length (CPIC 02042); 1 specimen $37-\mathrm{mm}$ preserved length (CPIC 02040).

INDIAN OCEAN AND RED SEA: Ataqa, head of the Gulf of Suez, Suez Bay, Egypt, 26 Jan 1967, 2 specimens 55- and 70-mm preserved length (LACM 180162). Colaba, Mumbai, India, 21 Dec 1964, 1 specimen 60-mm preserved length (CASIZ 082120).

CENTRAL PACIFIC: Devil's Point, Maricaban Island, Batangas, Philippines, 21.iii.2008, 1 specimen 13-mm preserved length (CASIZ 177500). Verde Island Passage, Batangas, Philippines, 13.v.2014, 2 specimens 43- and 45-mm preserved length (CASIZ 202048).

SOUTH AFRICA: Long Beach, Simon's Bay, Western Cape Province, South Africa, 6.i.2008, 1 specimen 83-mm preserved length (CASIZ 176327).

\section{Description}

External morphology. Body oval, slightly longer than wider. Parapodia reduced, almost completely fused together, leaving anterior and posterior foramens $\sim 1 / 3$ of parapodia length. Body usually covered with several primary papillae extremely variable in size and shape among specimens; primary papillae often ramified, with secondary branches typically shorter than the primary papillae; some specimens have few long and tentacular papillae, nearly as long as body width, with ramified secondary branches (Fig. 2A); others have much shorter, numerous primary papillae densely covering the body, and no apparently visible secondary branches (Fig. 2B). Dorsal body surface covered with numerous small tubercles among papillae. Dorso-anterior rhinophores enrolled, short, conical. Anterior, triangular, oral tentacles. Rhinophores and oral tentacles covered with papillae similar to those on body surface. Colour variable, dark grey to black. Papillae and 
tubercles much lighter, typically light grey or pinkish grey, sometimes with darker spots, giving the entire body a greyish to brownish appearance. Few, oval, bright blue spots can be present in some specimens.

Internal morphology. Shell absent. Radular formula $38 \times$ 31.1.31 in a 60-mm-long specimen from Colaba, India (CASIZ 082120), $35 \times 32.1 .32$ in a 83-mm-long specimen from Simon's Bay, South Africa (CASIZ 176327), and $30 \times 39.1 .39$ in a 37-mm-long specimen from Murcia, Spain (CPIC 02043). Rachidian teeth with robust, wide central cusp bearing central denticle plus 3-4 lateral denticles on each side, each with variable number of smaller, secondary denticles (Fig. $3 A, D$, $4 A, D, 5 A, D)$. Base of rachidian teeth wider than cusp, triangular with concave proximal end (Fig. $3 A, D, 4 A, D, 5 A, D$ ). Innermost lateral teeth with central cusp surrounded by 1-3 large blunt denticles on each side; both cusp and denticles often bearing smaller denticles (Fig. $3 A, D, 4 A, D, 5 A, D$ ). Mid-lateral teeth with elongate cusp and 0-3 elongate denticles on outer side (Fig. $3 B, E, 4 B, E, 5 B, E$ ). Outermost lateral teeth with very elongate cusp, with or without denticles (Fig. $3 C, F, 4 C, F, 5 C$, $F)$. Jaws composed of numerous, elongate, simple elements (Fig. 3J, 4J, 5J). Gizzard with several irregular, quadrangular to conical, plates (Fig. $3 G-I, 4 G-I, 5 G-I$ ). Two elongate structures (postradular armature) located at oesophagus insertion point, with numerous spines with elongate bases and triangular cusps (Fig. $3 K, 4 K, 5 K$ ). Male copulatory organ with elongate penial canal and strong anterior and posterior retractor muscles (Fig. $6 A, C, E$ ). Penial sheath located at distal end of male organ. Penis elongate, almost as long as wide, with curved apex and oval base; penis completely covered with large, conical spines (Fig. $6 B, D, F$ ).

\section{Range}

Widespread in tropical Atlantic and Indo-Pacific Oceans, including temperate regions in Spain, South Africa, Japan, Australia, and New Zealand, as well as in the Mediterranean, but absent from the Hawaiian Islands and the Eastern Pacific.

\section{Remarks}

De Blainville (1817) introduced the species name Bursatella leachii as the only member of the genus Bursatella, mentioning his description in an article on mollusks published in the 'Supplément à l'Encyclopédie Britannique'. However, de Blainville (1825, avertissement, p. v) subsequently highlighted that this work was never published because the manuscript was lost. De Blainville (1817) described B. leachii as being almost as large as a fist, translucent yellowish-white, with the body covered by small tentaculiform appendages irregularly arranged, longer on the anterior end of the head. De Blainville (1817) recognised that he did not know the locality in which the material was collected, but the specimen was deposited at the 'British Museum' [Natural History Museum of the UK]. The specimen was later illustrated by de Blainville (1827, pl. 43, fig. 6) and examined by Eales and Engel (1935), who provided additional illustrations and descriptions of the external morphology and anatomy, including the penis, which is covered with large spines. Eales and Engel (1935) also corroborated that the single specimen was the holotype and was collected in the Indian Seas. The description by Eales and Engel (1935) confirmed that the identity of B. leachii corresponds to the common usage of the name in modern literature.

Several other nominal species are currently regarded as synonyms of $B$. leachii but often placed in distinct subspecies. The systematics of all these species are discussed below in chronological order.

Audouin (1826) introduced the name Bursatella savigniana for a specimen collected in the Egyptian Red Sea and illustrated by Savigny (1809, pl. 2, fig. 2.1-2.13). The species was described as greenish grey with a large, thin, yellowish-grey foot having black dots on the dorsal posterior end. The body was described as covered with greyish blue branched papillae, with blackish spots at their bases. The illustrations of the live animal and some details of the internal anatomy (radular teeth) provided by Savigny (1809, pl. 2, fig. 2.1-2.13) corroborate the characteristics of this species and agree with the common use of the name Bursatella leachii; therefore, it is here confirmed to be a synonym as indicated by Eales and Engel (1935).

Rang (1828) redescribed Bursatella savigniana and reproduced the drawings by Audouin (1826) of this species. Rang (1828) included B. savigniana as well as other members of Notarchus (attributed to Cuvier) in Aplysia, which he defined very broadly to include most species of sea hares. Rang (1828) also introduced the new name Aplysia pleii from the Antilles (Caribbean Sea) as a distinct species but similar to $A$. savigniana . Rang (1828) considered that A. pleii was distinct from A. savigniana because of several characteristics, including a slight constriction behind the head, a greenish mantle, the presence of numerous clumps of branched or digitised appendages, and a foot clearly differentiated from the mantle, bordered by a fold and a considerable number of simple appendages. Rang (1828) also redescribed B. leachii and reproduced the drawing by de Blainville (1827) of this species. Rang (1828) argued that both A. savigniana and $A$. pleii are probably congeneric with $B$. leachii but because of the incomplete description of Bursatella and the fact that (at the time) it had not been reported by other scientists, he preferred to keep Bursatella as a separate genus. Eales and Engel (1935) regarded $A$. pleii as a synonym of $B$. leachii, but maintained it as a distinct subspecies from the Caribbean region, B. leachii pleii.

Rüppell and Leuckart (1828, 1830) described Notarchus laciniatus also from the Red Sea (El Tor) as a yellowish species with black spots and covered by papillae. The illustration of the animal clearly represents a Bursatella, and Rüppell and Leuckart $(1828,1830)$ recognised that their animal belongs to the same species illustrated by Savigny (1809), unaware that it has already been named B. savigniana by Audouin (1826). Eales and Engel (1935) also confirmed that $N$. laciniatus is also a synonym of $B$. leachii, but indicated that $N$. laciniatus, as well as B. savigniana, lack the green ocelli found in Indo-Pacific specimens of B. leachii and proposed that the Red Sea animals belong to a distinct subspecies, named $B$. leachii savigniana.

Quoy and Gaimard (1832) introduced the species name Aplysia cirrhifera based on specimens collected from 'aux Cerfs de l'Ile-de-France' [=Île aux Cerfs, Mauritius], and 
placed this taxon in the section of the notarchids, which included species of Aplysia that lack a shell. A. cirrhifera was described as being fairly large $(\sim 81 \mathrm{~mm}$ long), with a high dorsum, an elongated neck, very long tentacles, and covered with loose and ramified papillae; the illustration of the animal represents a pale, elongate species with numerous blue spots surrounded by red pigment and lacking longitudinal lines. Subsequent records of this species are controversial; for example, specimens from South Africa identified as A. cirrhifera by Bergh (1907) were considered to be B. leachii by Eales and Engel (1935). However, specimens examined by Eales (1952) also appear to fit within the known variability of $B$. leachii (see remarks of Bursatella). The only anatomical data available for $A$. cirrhifera are illustrations of the penial spines and radula of one of the syntypes provided by Pruvot-Fol (1934), and they seem consistent with those of $B$. leachii. Contributing to the mystery of $A$. cirrhifera is the lack of recent verifiable records. Eales (1952) noted that this species inhabits muddy shores, ranging from Mauritius to the Cape [=Cape of Good Hope, South Africa]. But none of the published field guides (Gosliner 1987; Zsilavecz 2007), surveys (Yonow and Hayward 1991; Yonow 2012) and websites (Bidgrain 2017) from this region illustrate specimens consistent with the original description of A. cirrhifera. As in the case of the genus Barnardaclesia, we can neither confirm nor deny the validity of $A$. cirrhifera; therefore, we regard it here as a probable synonym of $B$. leachii until more specimens become available, although this taxon could be a synonym of Phycophila euchlora Adams, 1861 (see below).

Couthouy in Gould (1852) described Bursatella lacinulata based on a single specimen collected in Rio de Janeiro, Brazil. The species was described as similar to $A$. savigniana but having a broader foot and a filamentous prolongation of the lips. The live animal was later illustrated by Couthouy in Gould (1856, pl. 16, fig. 269, 269a) as a green Bursatella with numerous black dots and branched papillae. Bergh (1902a, pl. 28, fig. 40-43, pl. 29, fig. 1-13) illustrated the anatomy of additional specimens from Rio de Janeiro under the name Aclesia pleii, including important diagnostic details such as the penis covered with spines and radular teeth morphology consistent with the common use of the name B. leachii. Eales and Engel (1935) concluded that $B$. lacinulata is a synonym of $B$. leachii, but maintained it as a distinct subspecies from Brazil, B. leachii lacinulata.

Stimpson (1855) introduced the name Notarchus cirrosus from China with a brief text and no illustrations. The animal was described as bluish-grey, sprinkled with black dots and the papillae edged with sulphur-yellow. Eales and Engel (1935) considered this description matching the common use of Bursatella leachii and did not find any distinctive characteristics to maintain $N$. cirrosus as a subspecies.

Cheeseman (1878) described Aclesia glauca from Auckland Harbour, New Zealand, as a pale greyish-brown to dull sea-green species with numerous irregularly shaped black blotches. The description was accompanied by a colour illustration of one of the live animals. Although no details of the anatomy were provided in the original description, with the exception of the confirmation of a multiseriate radula and the presence of gizzard plates, Eales and Engel (1935) regarded A. glauca as a synonym of $B$. leachii.
Cockerell (1893) introduced the species name Notarchus intrapictus from Jamaica based on a single specimen collected in Kingston. Cockerell (1893) described the live animal as prettily marbled with black and pale grey and papillae tinged reddish, the larger ones mottled with white. The anatomy was briefly described. According to Eales and Engel (1935), $N$. intrapictus undoubtedly belongs to $B$. leachii and matches other members of the Caribbean subspecies B. leachii pleii.

Hägg (1904) introduced Notarchus brevipes from El Tor, Egypt, and provided a detailed description of the external morphology based on a single preserved specimen. Hägg (1904) also reproduced a description of the external colour based on comments from the collector as greyish, blackish brown on the posterior end, with large, circular, greyish speckles on the dark brown parts of the body. Hägg (1904) compared $N$. brevipes with other similar species, but more extensively with $N$. savignianus, and enumerated several differences in external morphology that could easily be preservation artefacts. Although not explicitly discussed, Eales and Engel (1935) regarded this animal as a member of the Red Sea subspecies, B. leachii savigniana.

Griffin (1912) described Aclesia freeri in great detail from Manila Bay, Philippines, providing drawings of the live animal as well numerous anatomical details. Eales and Engel (1935) considered $A$. freer $i$ a synonym of $B$. leachii. The information provided, including the presence of penial spines, confirms the synonymy between $A$. freeri and $B$. leachii.

Engel (1926) described Aclesia africana based on 33 specimens collected in 'Knijsna' [=Knysna], South Africa. Engel (1926) regarded this species as similar to A. lacinulata. Eales and Engel (1935) considered A. africana as a synonym of B. leachii, but recognised the South African animals as a distinct subspecies because of their 'wooly appearance'.

Engel (1926) described Aclesia rosea from a single preserved animal collected in 'Baie de l'Ouest' [=west side of Ras Nouadhibou], western Sahara. Engel (1926) considered $A$. rosea as closely related to B. intrapicta, but decided to describe it as new 'for prudence'. Subsequently, Engel (1927) provided additional details on the anatomy. Eales and Engel (1935) considered $A$. rosea synonymous with $B$. leachii and distinct from the South African subspecies B. leachii africana.

O'Donoghue (1929) introduced Notarchus villosus based on a single specimen collected in Algoa Bay, South Africa. The specimen was preserved, but O'Donoghue (1929) provided numerous details of its external morphology and anatomy. Eales and Engel (1935) examined the holotype of this species, including the internal anatomy, and indicated that there is no doubt that it should be considered a synonym of B. leachii and a member of the subspecies B. leachii africana. However, Eales and Engel (1935) did not observe the penis, which was not present with the rest of the holotype; thus the synonymy of $N$. villosus and B. leachii cannot be verified here.

Allan (1932) introduced the species name Ramosaclesia rex based on several specimens collected near Sydney, Australia. The specimens were described as light green with a bluish tinge towards the sides; the papillae were transparent light yellow-brown, with conspicuous black rings and dots on their bases, changing to fine black speckling on the upper part of the 
main stems and on the papillae; large and small patches of black markings were over the dorsal surface, extending into the head. Eales and Engel (1935) considered that the data presented in the original description did not justify a distinct species, but that the Australian species could constitute another subspecies, Bursatella leachii rex, differing somewhat in the colour pattern from other subspecies. Because the penis of $R$. rex was not described, we cannot confirm its synonymy with B. leachii.

Hirase (1934) reported specimens from Japan as Aclesia freeri, but Eales and Engel (1935) considered the Japanese animals distinct enough to introduce a new variety [subspecies] name for it: B. leachii hirasei.

Eales and Engel (1935) did not describe a subspecies from West Africa but Bebbington (1969) introduced the subspecies name Bursatella leachii guineensis for specimens collected in Tema, Ghana, as well as additional material from Nigeria. Bebbington (1969) argued that the Ghanaian specimens have fewer villi on the body than those of the South African subspecies $B$. leachii africana and therefore were less woolly in appearance. Bebbington (1969) also indicated that the charcoal-grey colour of the Ghanaian specimens contrasted with the rose colour of the other West African specimens, that he erected to subspecies rank as B. leachii rosea. Bebbington (1969) described B. leachii guineensis as having peacock-blue ocelli on the body surface, which differ from those of the Indo-Pacific subspecies B. leachii leachii, in which the ocelli are green.

The subspecies scheme introduced by Eales and Engel (1935) and followed by other authors (Bebbington 1969, 1974, 1977; Marcus 1972) is based on a combination of geographic range and external characteristics. For example, in the Indo-Pacific basin, the subspecies B. leachii leachii can be distinguished from the Red Sea subspecies $B$. leachii savigniana and the South African subspecies B. leachii africana because of the possession of the ocelli on the body. These ocelli are not present in B. leachii savigniana, and $B$. leachii africana has a characteristic woolly appearance. However, not all subspecies can be recognised morphologically (Eales and Engel 1935; Bebbington 1969).

In the present study, molecular data confirmed that there are no consistent genetic differences between animals belonging to different subspecies and therefore there is no need to maintain this classification scheme. The only consistent differences were found between specimens from the Atlantic Ocean and those from the Indo-Pacific region, suggesting limited gene flow between these two regions.

\section{Bursatella ocelligera (Bergh, 1902)}

(Fig. 2C, 7, 8)

Aclesia ocelligera Bergh, 1902: 169-174, pl. 1, fig. 31-38, pl. 2, fig. 1-11.

Type locality: Koh Chang, Thailand.

Type material

Aclesia ocelligera Bergh, 1902, 2 syntypes (NHMD 91730, NHMD 91731).

\section{Material examined}

Anilao Pier, Balayan Bay, Batangas, Philippines, 6.v.2014, 1 specimen 20-mm preserved length, leg. C. Shipman (CASIZ 200587); 19.v.2014, 1 specimen 25-mm preserved length, leg. C. Shipman (CASIZ 201161).

\section{Description}

External morphology. Body oval, slightly longer than wider. Parapodia reduced, almost completely fused together, leaving small anterior and posterior foramens. Body covered with several ramified papillae, variable in size and shape among specimens. Papillae typically few, long, tentacular, with numerous secondary branches (Fig. 2C); secondary branches variable in length, some as long as primary papillae. Dorsal body surface covered with numerous small tubercles among papillae. Dorsoanterior rhinophores enrolled, short, conical. Anterior, triangular, oral tentacles. Rhinophores and oral tentacles covered with papillae similar to those on body surface. Colour variable, greenish grey to brown. Papillae much lighter, typically light grey, sometimes with black spots and stripes. Body surface with numerous small black and opaque white dots, and fewer oval, bright blue rounded spots, edged in black, and sometimes black lines.

Internal morphology. Shell absent. Radular formula $26 \times$ 18.1.18 in a 20-mm-long specimen from Batangas, Philippines (CASIZ 200587) and $26 \times 20.1 .20$ in a 25-mm-long specimen from Batangas, Philippines (CASIZ 201161). Rachidian teeth with robust, wide central cusp bearing central denticle plus 3 or 4 lateral denticles on each side, each with variable number of smaller, secondary denticles (Fig. $7 A, D$ ). Base of rachidian teeth wider than cusp, triangular with concave proximal end (Fig. 7A). Innermost lateral teeth with central cusp surrounded by 2 or 3 large blunt denticles on each side (Fig. $7 A, D$ ). Midlateral teeth with elongate cusp and 1 or 2 elongate denticles on outer side (Fig. $7 B, E$ ). Outermost lateral teeth with very elongate cusp, with or without denticles (Fig. $7 C, F$ ). Jaws composed of numerous, elongate, simple elements (Fig. 7J). Gizzard with several irregular, elongate plates (Fig. $7 G-I$ ). Two elongate structures (postradular armature) located posterior to radula, at oesophagus insertion point, with numerous spines with elongate bases and triangular cusps (Fig. $7 K$ ). Male copulatory organ with elongate penial canal and strong anterior and posterior retractor muscles (Fig. 8A, $C)$. Penial sheath located at distal end of male organ, separated from penial canal by a penial collar. Penis very elongate, narrow, smooth, lacking penial spines, with longitudinal groove (Fig. $8 B, D)$.

Range

Central Pacific Ocean, from Gulf of Thailand to Philippines.

\section{Remarks}

Bergh (1902b) introduced the name Aclesia ocelligera based on specimens collected in Koh Chang, Thailand. The description was based on preserved specimens, thus their live appearance was unknown. Bergh (1902b) stated that the penis of this species has soft cones but lacks a chitinous covering. Eales and Engel (1935) indicated that the lack of 

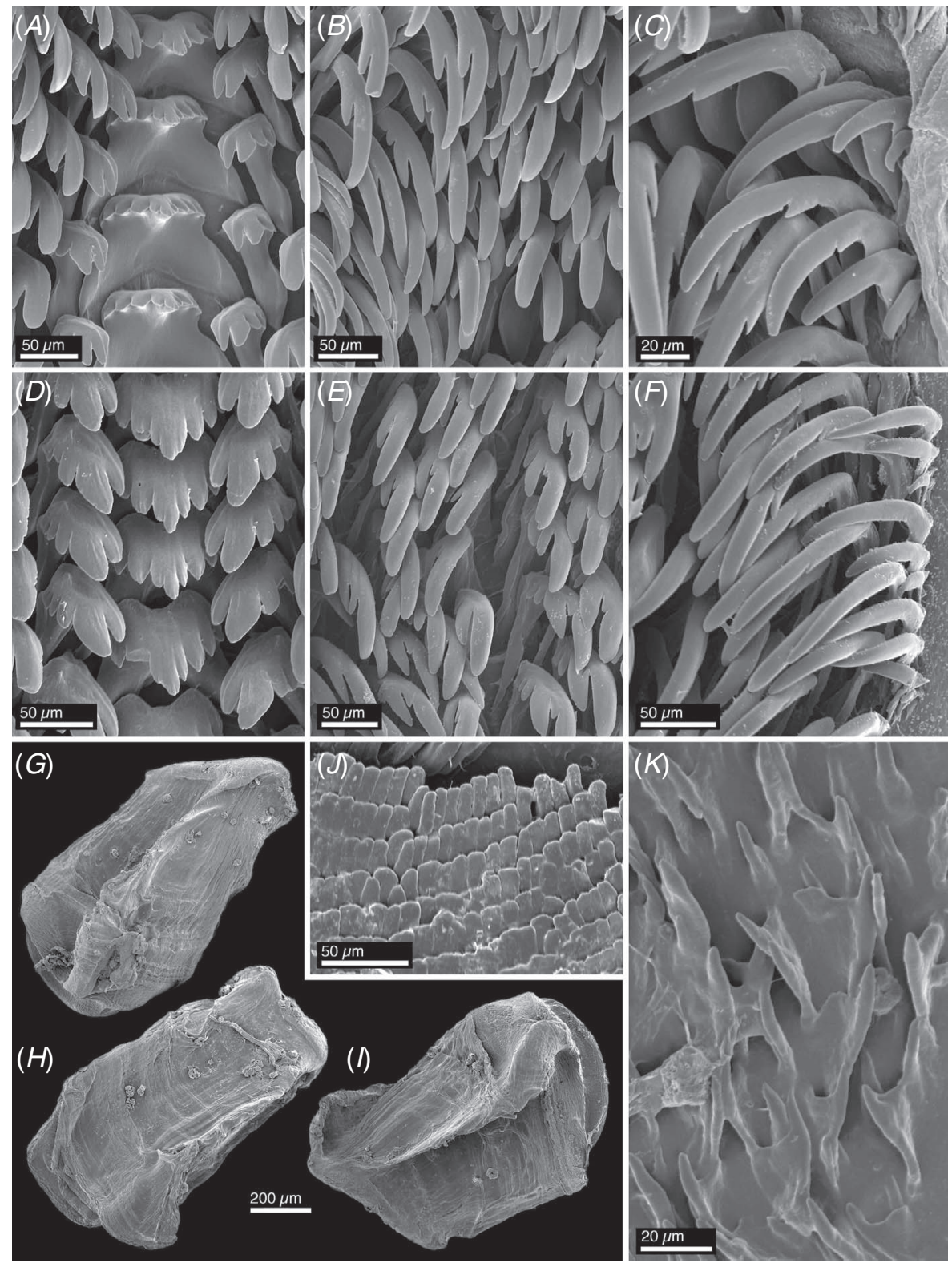

Fig. 7. Scanning electron micrographs of the anatomy of Bursatella ocelligera (Bergh, 1902), specimens from Anilao, Philippines. $A-C$, Radular teeth (CASIZ200587) (EN107): rachidian and inner lateral teeth $(A)$, mid-lateral teeth $(B)$, outer lateral teeth $(C) . D-F$, Radular teeth (CASIZ 201161) (EN106): rachidian and inner lateral teeth $(D)$, mid-lateral teeth $(E)$, outer lateral teeth $(F)$. $G-I$, Gizzard plates (CASIZ 200587) (EN107). $J$, Jaw elements (CASIZ 200587) (EN107). K, Postradular armature (CASIZ 200587) (EN107).

spines in the penis is probably an error, but this is the only description of an Indo-Pacific Bursatella with an unarmed penis and therefore we propose to use this name for this species.

\section{Genus Stylocheilus Gould, 1852}

Stylocheilus Gould, 1852: 224-225.

Type species: Stylocheilus lineolatus Gould, 1852, by subsequent designation by Kobelt (1876).

\section{Diagnosis}

Body elongate, soft, with long triangular posterior end of foot (tail). Body surface, rhinophores, and oral tentacles covered with numerous short conical papillae, simple or ramified. Mantle cavity with reduced opening, containing large gill, surrounded or covered by short parapodia. Shell absent. Radula with broad rachidian teeth and inner lateral teeth denticulate. Penis elongate, narrow, armed with numerous spines; penial canal with large spines. 


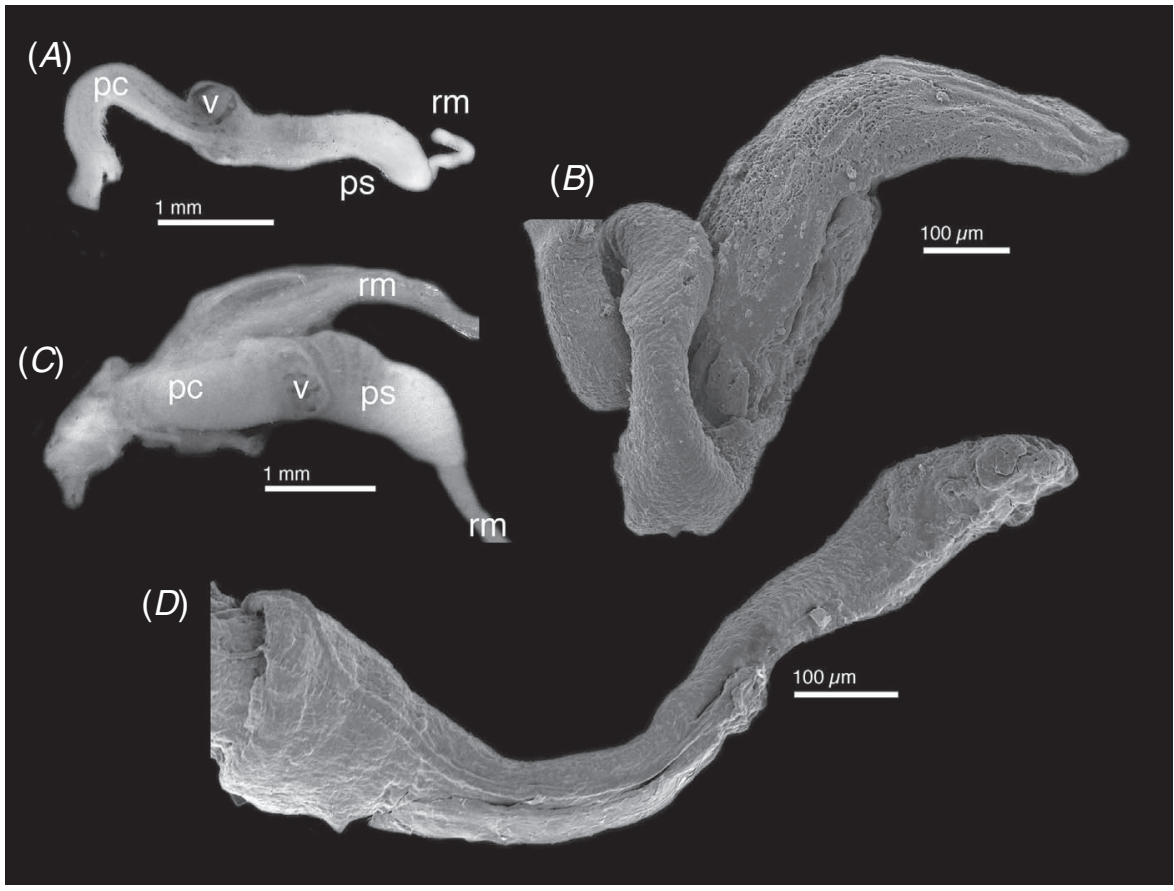

Fig. 8. Penial anatomy of Bursatella ocelligera (Bergh, 1902), specimens from Anilao, Philippines. $A, B$, Specimen from Anilao, Philippines (CASIZ 201161) (EN106): complete male reproductive organs $(A)$, penis $(B)$. $C, D$, Specimen from Anilao, Philippines (CASIZ 200587) (EN107): complete male reproductive organs $(C)$, penis $(D)$. Abbreviations: rm, retractor muscle; pc, penial canal; ps, penial sheath; v, penial collar.

\section{Remarks}

The genus name Stylocheilus was introduced by Gould (1852) based on two new species, S. lineolatus Gould, 1852 and S. quercinus Gould, 1852, as well as on Aplysia longicauda Quoy \& Gaimard, 1824. Pilsbry $(1895,1896)$ considered Stylocheilus to be a subdivision of Notarchus, but Eales and Engel (1935) regarded it as a valid and distinct genus. This opinion is now widely accepted (Bebbington 1974, 1977; Marcus 1972). Eales and Engel (1935) listed Aplysia longicauda Quoy \& Gaimard 1824 as the type species of Stylocheilus, but Kobelt (1876) had previously designated Stylocheilus lineolatus Gould, 1852 as the type.

The existence of two distinct, pantropical species within Stylocheilus (Bebbington 1974, 1977; Marcus 1972; Rudman 1999) has long been recognised. One of the species has a translucent greyish body completely covered with longitudinal dark grey lines, and often with patches of green, brown, and white. Morphologically, this species has a fairly short posterior end of the body (metapodium) and the body surface bears ramified papillae. This species is mainly benthic, but can be found on floating objects and algae nearshore. The second species is a uniform yellow or green, with few spots, usually blue, often with a reddish edge. Around the spots are clear rings, each surrounded by a ring of orange. In some specimens the red edge dominates and the blue spots appear red. White and blue spots without a surrounding ring can also occur, and papillae are sparse and seldom branched. This species is exclusively pelagic, and it is found on floating Sargassum algae. Most authors have referred to the benthic species as S. longicaudus and the pelagic species as $S$. citrinus (Marcus 1972) but Rudman (1999) showed that the original description of Stylocheilus longicaudus (Quoy \& Gaimard, 1825) is consistent with the characteristics of the pelagic species and that the name Stylocheilus striatus (Quoy \& Gaimard, 1832) is the oldest available for the benthic species. More recently, Yonow (2012) treated $S$. striatus as a probable synonym of $S$. longicaudus, but did not discuss evidence presented by Rudman (1999) that they are distinct species.

In this study, we have only examined benthic specimens but found that they do not constitute a single pantropical species, but three distinct species occur in the Indo-Pacific, eastern Pacific, and tropical Atlantic. These species are herein described and characterised.

\section{Stylocheilus striatus (Quoy \& Gaimard, 1832)}

(Fig. 9A, $B, 10,11$ )

Aplysia striata Quoy \& Gaimard, 1832: 315-316, pl. 24, fig. 9-11.

Type locality: 'Dorey’ [=Manokwari], New Guinea Island.

Stylocheilus lineolatus Gould, 1852: 225-226, fig. 270, 270a.

Type locality: Honolulu, Hawaiian Islands.

?Stylocheilus quercinus Gould, 1852; 226, fig. 271

Type locality: Levuka, 'Feejee Islands' [=Fiji]. 
Notarchus lineolatus Stimpson, 1855: 378.

Type locality: 'Loo Choo’ [=Ryukyu Islands].

Notarchus stimpsoni Pilsbry, 1895-1896: 142 [replacement name for Notarchus lineolatus Stimpson, 1855, not Stylocheilus lineolatus Gould, 1852]

\section{Type material}

Aplysia striata Quoy \& Gaimard, 1832, 1 syntype (MNHN IM2000-24199). Stylocheilus lineolatus Gould, 1852, location unknown, not in Johnson (1964). Stylocheilus quercinus Gould, 1852, location unknown, not in Johnson (1964). Notarchus lineolatus Stimpson, 1855, most likely destroyed (Dance 1966).
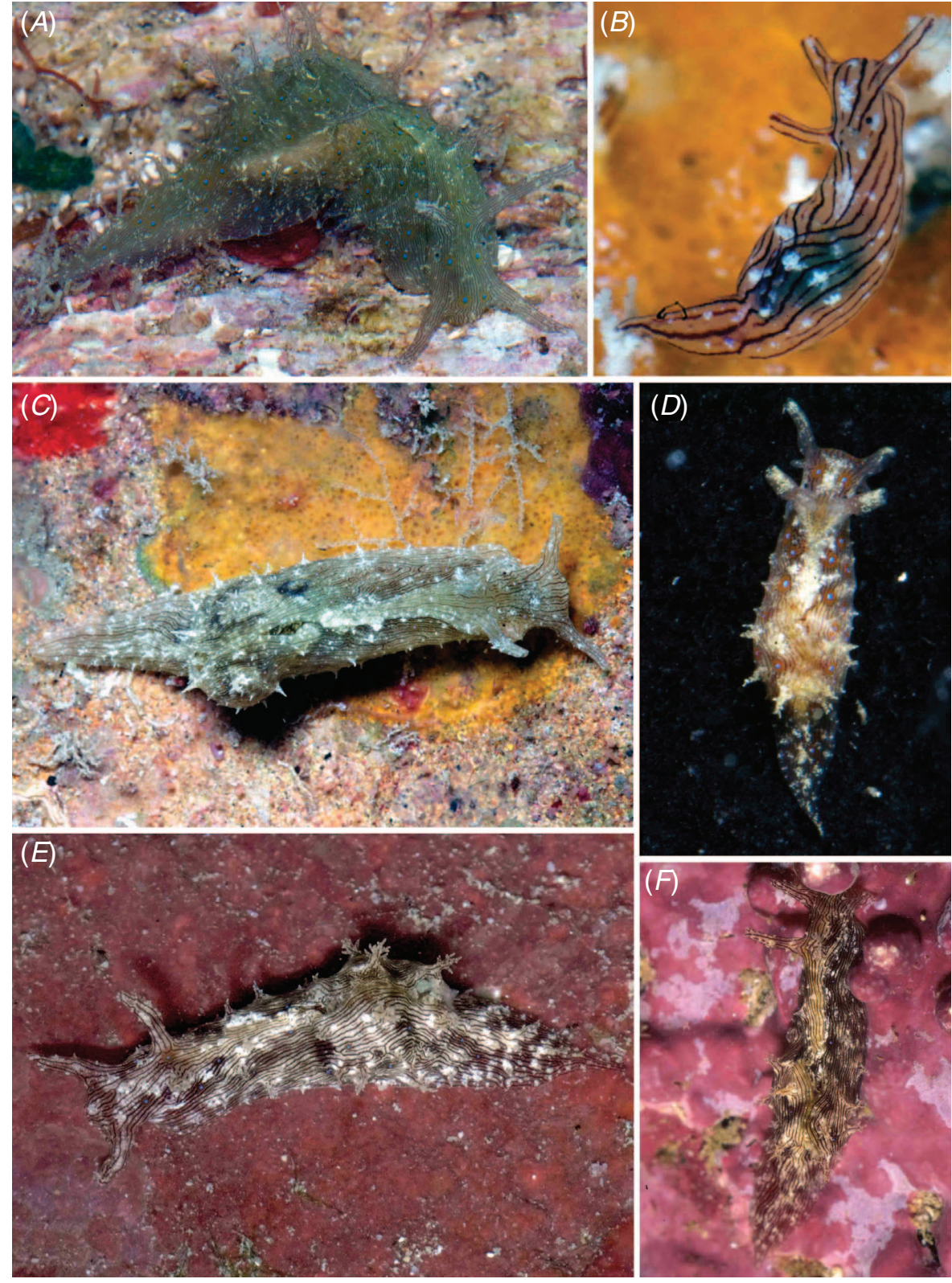

Fig. 9. Photographs of live animals. A, Stylocheilus striatus (Quoy \& Gaimard, 1832), specimen from Batangas, Philippines (CASIZ 177500) (EN102). B, Stylocheilus striatus (Quoy \& Gaimard, 1832), specimen from Vanuatu. C, Stylocheilus polyomma (Mörch, 1863), specimen from Curaçao (LACM 2004-94.5). D, Stylocheilus polyomma (Mörch, 1863), specimen from Bocas del Toro, Panama (CPIC 01590). E, Stylocheilus rickettsi (MacFarland, 1966), specimen from Huatulco, Mexico. F, Stylocheilus rickettsi (MacFarland, 1966), specimen from Costa Rica. 

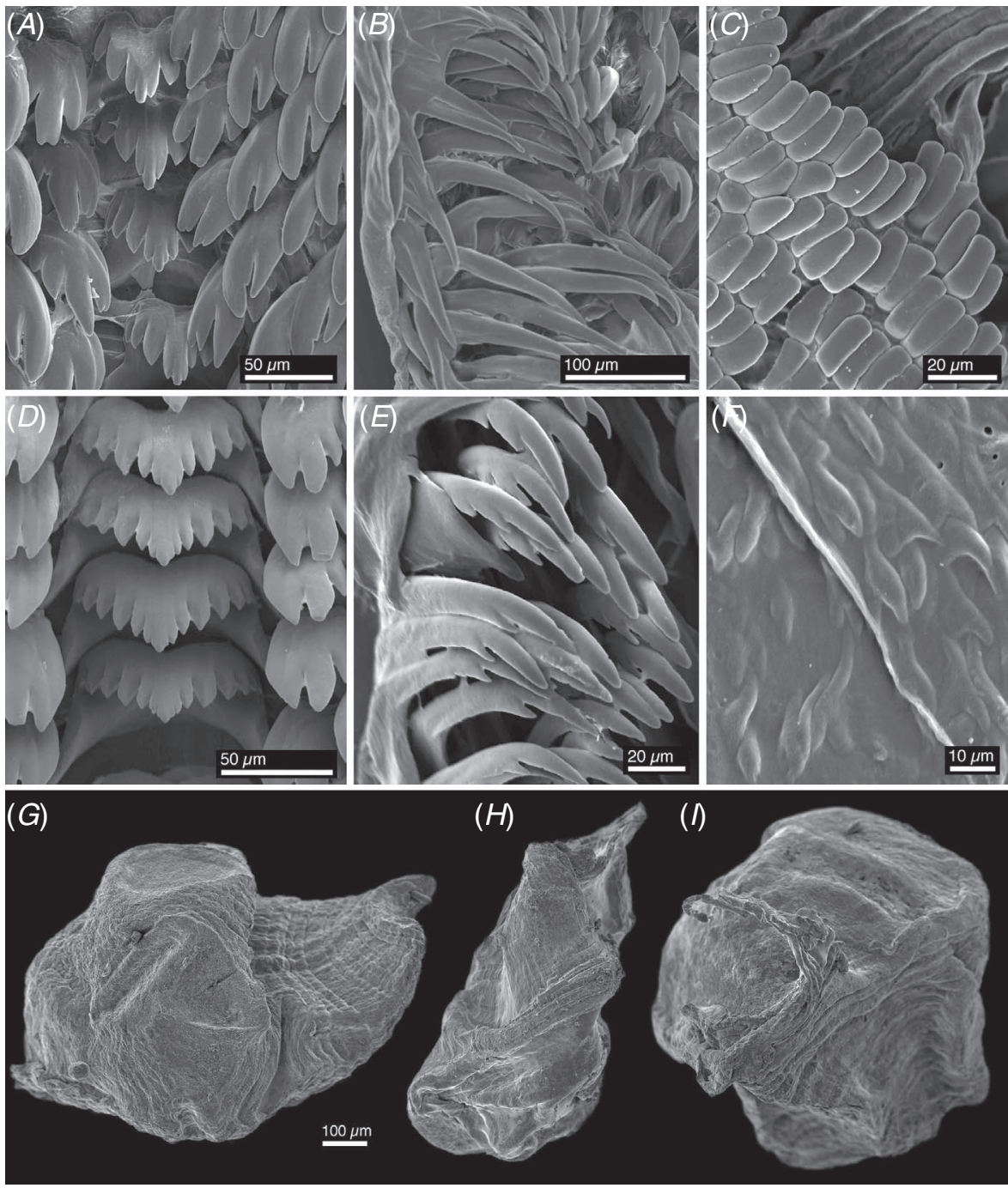

Fig. 10. Scanning electron micrographs of the anatomy of Stylocheilus striatus (Quoy \& Gaimard, 1832), specimens from the Indo-Pacific region. $A, B$, Radular teeth of a specimen from the Hawaiian Islands (CPIC 01133): rachidian and inner lateral teeth $(A)$, outer lateral teeth $(B)$. $C$, Jaw elements of a specimen from the Hawaiian Islands (CPIC 01133). D, E, Radular teeth of a specimen from the Philippines (CASIZ 177500) (EN102): rachidian and inner lateral teeth $(D)$, outer lateral teeth $(E)$. $F$, Postradular armature of a specimen from the Philippines (CASIZ 177500) (EB102). G-I, Gizzard plates of a specimen from the Hawaiian Islands (CPIC 01133).

\section{Material examined}

Krangket Island, Madang, Papua New Guinea, 6.xi.2012, 1 specimen 4$\mathrm{mm}$ preserved length (CPIC 00819). Tinian, Marianas Islands, 16.x.2008, 1 specimen $15-\mathrm{mm}$ preserved length (LACM 180142). Kona, Hawai'i, Hawaiian Islands, 1.viii.2014, 1 specimen 18-mm preserved length (CPIC 01133). Hekili Point, Maui, Hawaiian Islands, 13.vi.2011, 4 specimens 15-22-mm preserved length (CPIC 00295); 14.vi.2011, 1 specimen 6-mm preserved length (CPIC 00312). Maliko Bay, Maui, Hawaiian Islands, 16. vi.2011, 6 specimens 5-8-mm preserved length (CPIC 00334); 22.vi.2016, 1 specimen 5-mm preserved length (CPIC 01660); 22.vi.2016, 6 specimens 4-6-mm preserved length (CPIC 01677). Mama's Fish House tidepool, Maui, Hawaiian Islands, 25.vi.2016, 2 specimens 6-7$\mathrm{mm}$ preserved length (CPIC 01700); 27.vi.2016, 1 specimen 3-mm preserved length (CPIC 01733); 28.vi.2016, 5 specimens 6-8-mm preserved length (CPIC 01745); 1 specimen 4-mm preserved length (CPIC 01753); 8 specimens 4-7-mm preserved length (CPIC 01756).
Anini Beach, Kaua'i, Hawaiian Islands, 12.vii.2016, 1 specimen 9-mm preserved length (CPIC 01782).

\section{Description}

External morphology. Body narrow, elongate, with conical posterior end of foot (metapodium) occupying nearly $1 / 4$ of the body length. Parapodia reduced, almost completely fused together, leaving small anterior and posterior foramens. Parapodia region of body enlarged, forming conspicuous dorsal bump. Body covered with several ramified papillae, variable in size and shape among specimens. Primary papillae typically few, long, tentacular, with numerous secondary branches (Fig. 9A, B); secondary branches shorter than papillae. Dorso-anterior rhinophores enrolled, tentacular, elongate, with wider tips. Anterior oral tentacles, with same 


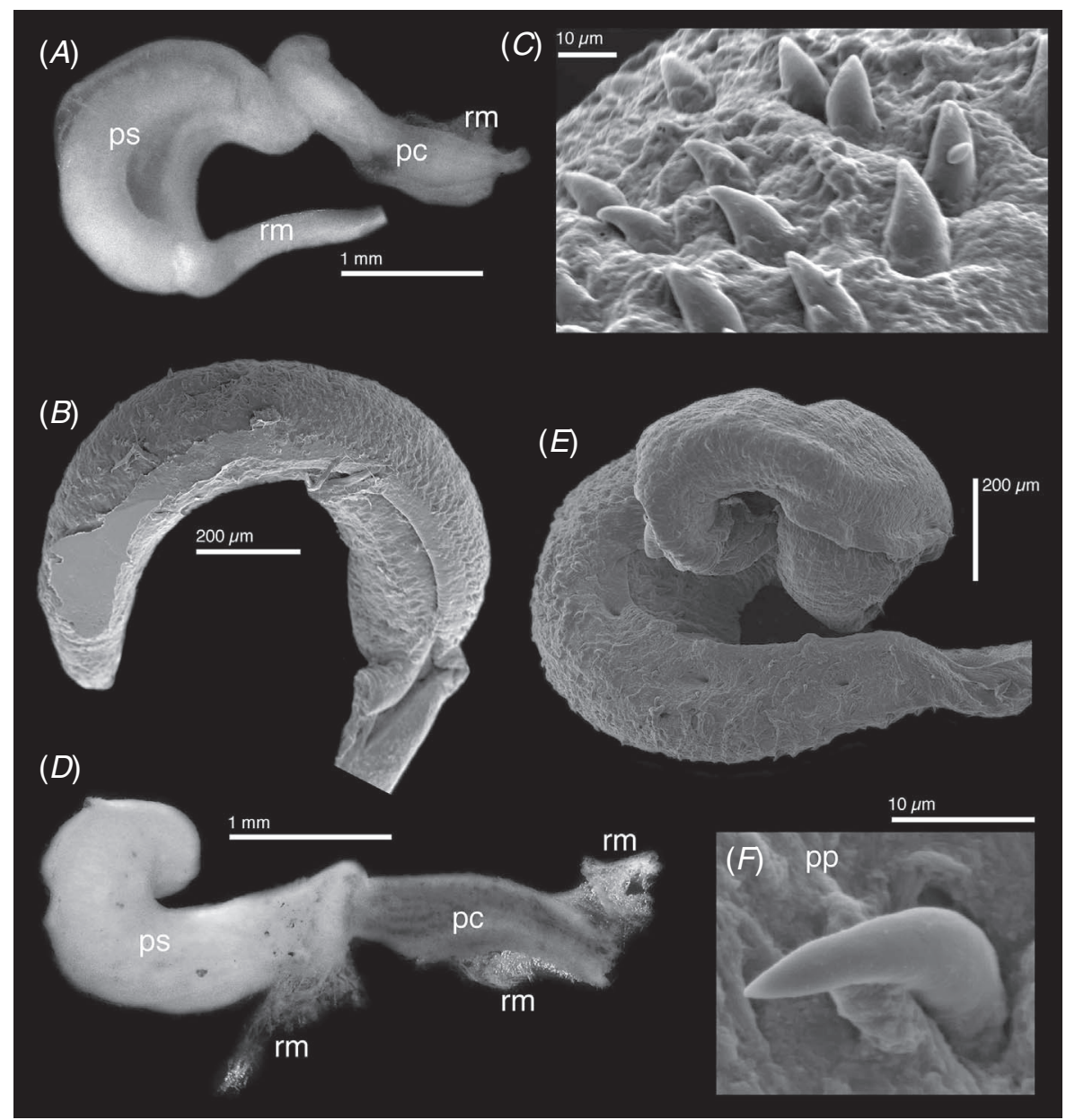

Fig. 11. Penial anatomy of Stylocheilus striatus (Quoy \& Gaimard, 1832), specimens from the Indo-Pacific region. $A-C$, Specimen from the Hawaiian Islands (CPIC 01133): complete male reproductive organs $(A)$, scanning electron micrograph (SEM) of the penis $(B)$, SEM detail of penial spines (C). $D-F$, Specimen from the Philippines (CASIZ 177500) (EN102): complete male reproductive organs $(D)$, SEM of the penis $(E)$, SEM detail of penial spines $(F)$. Abbreviations: rm, retractor muscle; pc, penial canal; ps, penial sheath.

shape as rhinophores. Rhinophores and oral tentacles covered with papillae, shorter than those on body surface. Colour variable, greenish grey to reddish brown. Body surface with numerous longitudinal black lines forming irregular patterns and fewer conspicuous bright blue spots. Papillae lighter than body with some black stripes. Juvenile specimens devoid of papillae, with conspicuous black lines and some bright blue oval spots, as well as opaque white patches (Fig. 9B).

Internal morphology. Shell absent. Radular formula $27 \times$ 20.1.20 in 18-mm-long specimen from Kona, Hawai'i (CPIC 01133 ) and $21 \times 14.1 .14$ in a 8 -mm-long specimen from Maliko Bay, Maui (CPIC 00334). Rachidian teeth with robust, wide central cusp bearing sharp central denticle plus 3 or 4 lateral denticles on each side. Lateral denticles smooth, but central denticle with small secondary denticle on each side (Fig. 10A, D). Base of rachidian teeth wider than cusp, triangular with concave proximal end. Innermost lateral teeth with blunt central cusp surrounded by large blunt inner denticle and 2 or 3 outer denticles on each side (Fig. 10A, D). Mid-lateral and outer teeth with sharp elongate cusps and 1 or 2 sharp denticles on outer side (Fig. 10B,E). Jaws composed of numerous simple elements (Fig. 10C). Gizzard with several irregular plates (Fig. 10G-I). Two elongate structures (postradular armature) located posterior to radula, at oesophagus insertion point, with numerous triangular spines (Fig. 10F). Male copulatory organ with long penial canal and strong anterior and posterior retractor muscles (Fig. $11 A, D$ ). Penial sheath longer and wider than penial canal, located at distal end of male organ. Penis narrow and elongate, with longitudinal groove (Fig. $11 B, E$ ) and numerous minute spines (Fig. 11C, F).

\section{Range}

Indo-Pacific tropics, from Red Sea to Hawaiian Islands.

\section{Remarks}

Quoy and Gaimard (1832) introduced the name Aplysia striata based on specimens collected on floating algae ('fucus') in 
'Dorey' [=Manokwari], New Guinea Island, Indonesia, and indicated that everything suggests it is a pelagic species. The taxon was described as very elongate and having a greenish yellow body streaked very finely with reddish-brown longitudinal lines as well as several large, round, yellowish spots with blue centres. Quoy and Gaimard (1833) also provided illustrations for one of the specimens, which are consistent with the description. On the basis of the description and illustrations, which clearly indicate the presence of longitudinal lines, we agree with Rudman (1999) in considering this the oldest available name for the benthic Stylocheilus; because the type locality is in the central Pacific, we also regard this as the valid name for the Indo-Pacific species.

Gould (1852) described two new species of Stylocheilus from the tropical Pacific. The first one, Stylocheilus lineolatus Gould, 1852, was found on a coral reef in Honolulu, Hawaiian Islands. This species was described as pale grass-green in colour, ornamented with longitudinal, parallel, contorted, rusty lines, and scattered ocelli of unequal size. One specimen was darker in colour and had shorter papillae, but was considered to be a member of the same species. The second species, Stylocheilus quercinus Gould, 1852, was based on specimens collected from Fiji, and was described as having an elongated body, wood-coloured, and longitudinally grained with numerous unequal, rusty lines or folds. We have not observed other species of Stylocheilus with this colour pattern, but because of the geographic location of the specimens and the presence of longitudinal lines, we provisionally also consider $S$. quercinus to be a synonym of S. striatus.

Stimpson (1855) introduced the name Notarchus lineolatus Stimpson, 1855 for specimens collected in 'Loo Choo' [=Ryukyu Islands]. The animals were described as greenish with minute, crowded, longitudinal black lines and a few small, round, nucleated spots on the sides. The characteristic longitudinal dark lines mentioned in the original description allow us again to place $N$. lineolatus in the synonymy of S. striatus. However, a few decades later, Pilsbry (1895, 1896) transferred Stylocheilus lineolatus to the genus Notarchus, and thus Notarchus lineolatus Stimpson entered in homonymy with Notarchus lineolatus (Gould).

At the same time, Pilsbry $(1895,1896)$ proposed the replacement name Notarchus stimpsoni Pilsbry, 1896 for Stimpson's Notarchus lineolatus. The description of this species is again consistent with the characteristics of the benthic Indo-Pacific species of Stylocheilus, and therefore it is considered to be another synonym of $S$. striatus.

\section{Stylocheilus polyomma (Mörch, 1863)}

(Fig. $9 C, D, 12,13)$

Notarchus polyomma Mörch, 1863: 25.

Type locality: St Thomas and St Croix.

Type material

Notarchus polyomma Mörch, 1863, 1 syntype (NHMD 91535).

\section{Material examined}

Lake Worth Lagoon, Florida, USA, 28.viii.2008, 1 specimen 6.5-mm preserved length, leg. A. Dimitris (CPIC 00116). Isla Pajaros, Bocas del Toro, Panama, 1.viii.2015, 13 specimens 1-4-mm preserved length, leg. J. Goodheart et al. (CPIC 01590). In front of Carmabi Foundation, Piscadera Baai, Curaçao, 16.viii.2004, 1 specimen 13-mm preserved length (LACM 2004-94.5). St Ann's Bay, Jamaica, 26.v.2006, 1 specimen 14-mm preserved length, leg. A. DuPont (LACM 173250). Punta Cahuita, Limón, Costa Rica, 31.x.1986, 5 specimens 6-7-mm preserved length (LACM 1986-205.1).

\section{Description}

External morphology. Body narrow, elongate, with conical posterior end of foot occupying nearly $1 / 4$ of the body length. Parapodia reduced, almost completely fused together, leaving small anterior and posterior foramens. Parapodia region of body enlarged, forming conspicuous dorsal bump. Body covered with several ramified papillae, variable in size and shape among specimens. Primary papillae typically few, long, tentacular, with numerous secondary branches (Fig. 9C,D); secondary branches shorter than papillae. Dorso-anterior rhinophores enrolled, tentacular, elongate. Anterior oral tentacles, with same shape as rhinophores. Rhinophores and oral tentacles covered with papillae, shorter than those on body surface. Colour variable, greenish grey to reddish brown. Body surface with numerous longitudinal black lines forming irregular patterns and fewer opaque white dots. Papillae lighter than body, cream to white, with some black stripes. Juvenile specimens with conspicuous bright blue oval spots, edged in black (Fig. 9D).

Internal morphology. Shell absent. Radular formula $19 \times$ 10.1.10 in a 6.5-mm-long specimen from Lake Worth Lagoon, Florida (CPIC 00116) and $24 \times 18.1 .18$ in a 14-mm-long specimen from St Ann's Bay, Jamaica (LACM 173250). Rachidian teeth with robust, wide central cusp bearing sharp central denticle plus 3 lateral denticles on each side. Lateral denticles smooth, but central denticle with small secondary denticle on each side (Fig. 12A,D). Base of rachidian teeth much wider than cusp, triangular with concave proximal end. Innermost lateral teeth with blunt central cusp surrounded by large blunt inner denticle and 2 or 3 outer denticles (Fig. 12A, D). Mid-lateral and outer teeth with sharp elongate cusps and 1 or 2 sharp denticles on outer side (Fig. 12B, E). Jaws composed of numerous simple elements (Fig. 12C). Gizzard with several irregular plates (Fig. 12G-I). Two elongate structures (postradular armature) located posterior to radula, at oesophagus insertion point, with numerous triangular spines (Fig. 12F). Male copulatory organ with long penial canal and strong anterior and posterior retractor muscles (Fig. 13A, D). Penial sheath as long and wide as penial canal, located at the distal end of male organ. Penis narrow and elongate, blunt apically, with longitudinal groove (Fig. 13B) and numerous minute spines (Fig. 13C). Vagina with large rounded structures bearing conical spines on centres (Fig. 13E).

Range

Western Atlantic Ocean, from Florida to Brazil. 

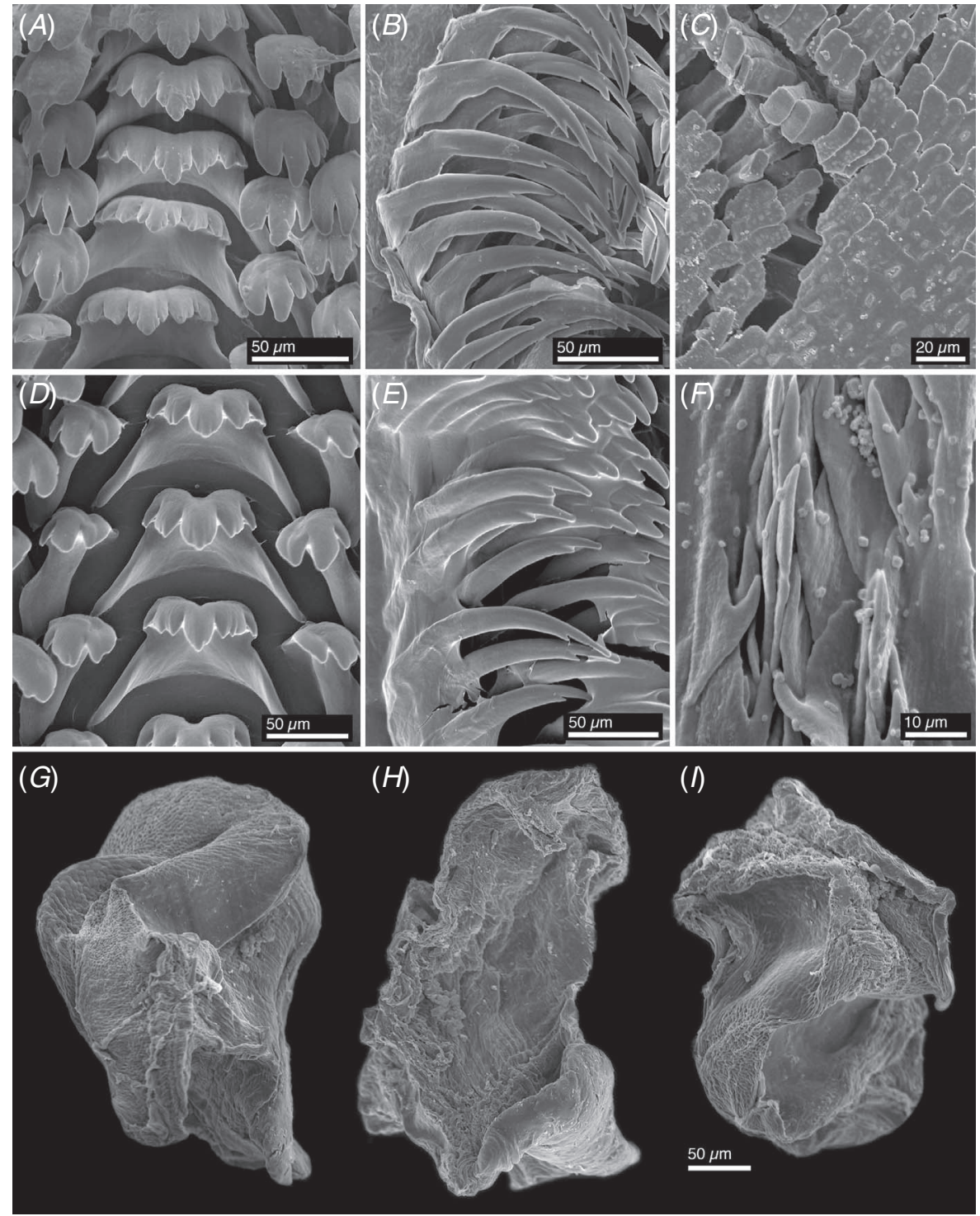

Fig. 12. Scanning electron micrographs of the anatomy of Stylocheilus polyomma (Mörch, 1863), specimens from the Atlantic region. $A, B$, Radular teeth of a specimen from Florida (CPIC 00116) (JS13): rachidian and inner lateral teeth $(A)$, outer lateral teeth $(B)$. $C$, Jaw elements of a specimen from Florida (CPIC 00116) (JS13). D, E, Radular teeth of a specimen from Jamaica (LACM 173250): rachidian and inner lateral teeth $(D)$, outer lateral teeth $(E) . F$, Postradular armature of a specimen from Jamaica (LACM 173250). G-I, Gizzard plates of a specimen from Florida (CPIC 00116) (JS13).

\section{Remarks}

Mörch (1863) introduced the name Notarchus polyomma based on a specimen collected from St Thomas and one from St Croix. The animals were not illustrated, but one of the specimens (from St Thomas) was described as having an elongate body, pale green in colour, with longitudinal dark lines and numerous scarlet round spots (ocelli). The second specimen (from St Croix) was preserved and described as pale yellowish with longitudinal dark lines. Mörch (1863) recognised that this species was similar to $A$. striata but differed by having more ocelli and the shape of the papillae.

Stylocheilus rickettsi (MacFarland, 1966)

$$
\text { (Fig. 9E, F, 14, 16) }
$$

Aclesia rickettsi MacFarland, 1966: 27-32, pl. 6, fig. 9, pl. 8, fig. 16-25, pl. 9, fig. $8-12$.

Type locality: Punta Lobos, Espíritu Santo Island, Baja California Sur, Mexico and Bahía de la Paz, Baja California Sur, Mexico. 


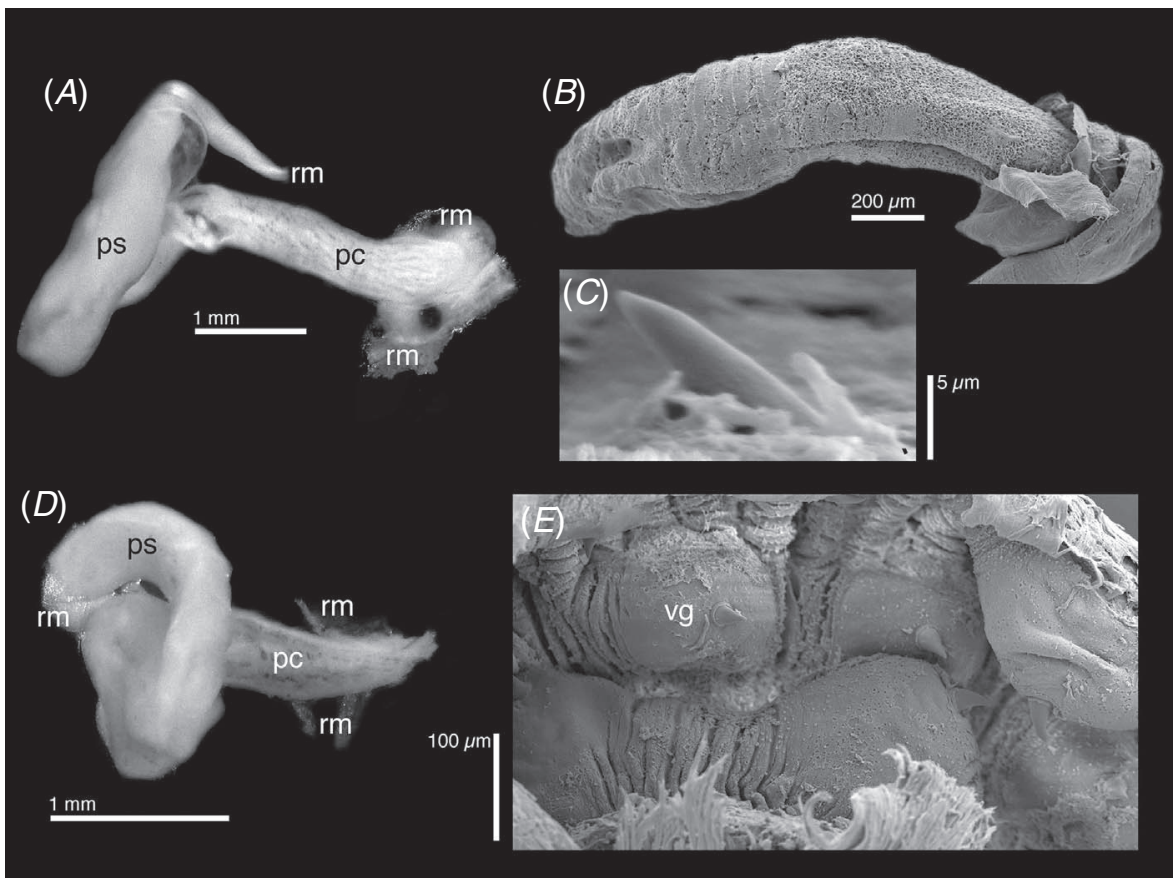

Fig. 13. Reproductive anatomy of Stylocheilus polyomma (Mörch, 1863), specimens from the Atlantic region. $A-C$, Specimen from Jamaica (LACM 173250): complete male reproductive organs $(A)$, scanning electron micrograph (SEM) of the penis $(B)$, SEM detail of a penial spine $(C) . D$, Specimen from Florida (CPIC 00116) (JS13), complete male reproductive organs. E, SEM of vaginal spines. Abbreviations: rm, retractor muscle; pc, penial canal; ps, penial sheath; $v$, vaginal spine.

\section{Type material}

Holotype (USNM 575219), 1 paratype (CASIZ 88013).

\section{Material examined}

San Carlos, Sonora, Mexico, Nov. 1975, 7 specimens 9-12-mm preserved length, leg. Forest and Poorman (LACM 180143). Bahía Algodones, San Carlos, Sonora, Mexico, Oct. 1976, 8 specimens 10-24-mm preserved length, leg. Forest and Poorman (LACM 24997). Punta Palmilla, Baja California, Mexico, 2.iv.1966, 1 specimen 26-mm preserved length, leg. McLean et al. (LACM 1966-11.27). El Tule, Canelo Bay, Baja California, Mexico, 6.iv.1966, 4 specimens 12-25-mm preserved length, leg. McLean et al. (LACM 1966-16.32). La Paz, Baja California Sur, Mexico, 3.vi.1973, 1 specimen $17-\mathrm{mm}$ preserved length, leg. Janss (LACM 179118). Islas Marietas, Jalisco, Mexico, 2.v.2002, 1 specimen 9-mm preserved length (CPIC 00550). Isla del Caño, Puntarenas, Costa Rica, 18-19.iii.1972, 2 specimens 8- and 13-mm preserved length, leg. McLean (LACM 197268.46). Puerto Parker, Costa Rica, 9.ii.1935, 15 specimens 11-23-mm preserved length (LACM 1935-108.4). Islas Secas, Panama, 4.ii.1935, 4 specimens 10-12-mm preserved length (LACM 1935-86.13). Canal de Afuera, Veraguas, Panama, 7.v.2003, 4 specimens 4-5-mm preserved length, leg Hermosillo (LACM 153367).

\section{Description}

External morphology. Body narrow, elongate, with conical posterior end of foot occupying nearly $1 / 4$ of the body length. Parapodia reduced, almost completely fused together, leaving small anterior and posterior foramens. Parapodia region of body enlarged, forming conspicuous dorsal bump. Body covered with several ramified papillae, variable in size and shape among specimens. Primary papillae typically few, long, tentacular, with numerous secondary branches (Fig. 9E, F); secondary branches shorter than papillae. Dorso-anterior rhinophores enrolled, tentacular, elongate. Anterior oral tentacles, with same shape as rhinophores. Rhinophores and oral tentacles covered with papillae, shorter than those on body surface. Colour variable, greenish grey to dark brown. Body surface with numerous longitudinal black lines forming irregular patterns, opaque white patches irregularly arranged and few small bright blue spots. Juvenile specimens with conspicuous black lines, otherwise similar to adults (Fig. $9 F$ ).

Internal morphology. Shell absent. Radular formula $24 \times$ 27.1.27 in 23-mm-long specimen from Puerto Parker, Costa Rica (LACM 135-108.4) and $28 \times 20.1 .20$ in a 24-mm-long specimen from Sonora, Mexico (LACM 24997). Rachidian teeth with robust, wide central cusp bearing sharp central denticle plus 3 lateral denticles on each side. Lateral denticles smooth, but central denticle with small secondary denticle on each side (Fig. 14A,D). Base of rachidian teeth much wider than cusp, triangular with concave proximal end. Innermost lateral teeth with blunt central cusp surrounded by large blunt inner denticle and 2 outer denticles on each side (Fig. 14A, D). Mid-lateral and outer teeth with sharp elongate cusps and 1 or 2 sharp denticles on outer side (Fig. 14B,E). Jaws composed of numerous simple elements (Fig. 14C). Gizzard with several irregular plates (Fig. 14G-I). Two elongate structures (postradular armature) located posterior to radula, at oesophagus insertion point, with numerous, very small, triangular spines (Fig. 14F). Male copulatory organ with short penial canal and strong anterior and posterior retractor muscles (Fig. 15A, D, G). Penial sheath twice as long and wide 

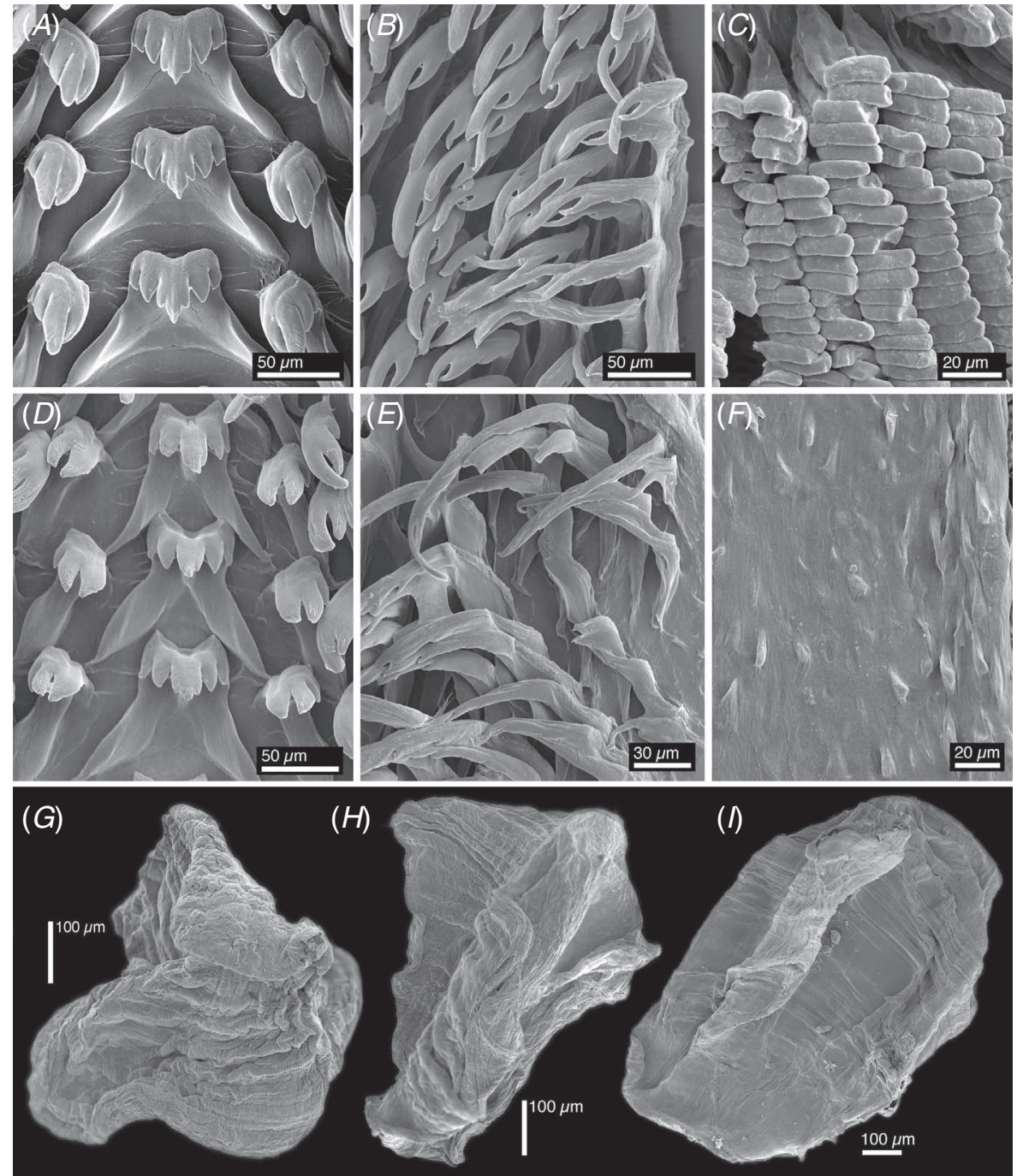

$(H)$

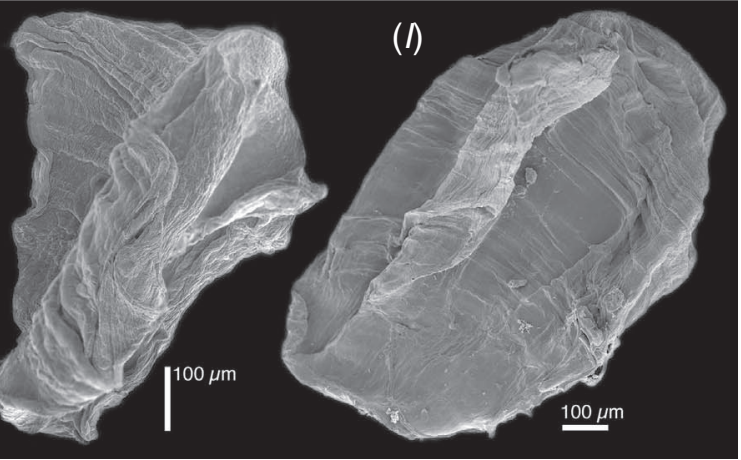

Fig. 14. Scanning electron micrographs of the anatomy of Stylocheilus rickettsi (MacFarland, 1966), specimens from the Eastern Pacific region. $A, B$, Radular teeth of a specimen from Puerto Parker, Costa Rica (LACM 135-108.4): rachidian and inner lateral teeth $(A)$, outer lateral teeth $(B)$. $C$, Jaw elements of a specimen from Islas Secas, Panama (LACM 1935-86.13). $D, E$, Radular teeth of a specimen from San Carlos Bay, Sonora, Mexico (LACM 24997): rachidian and inner lateral teeth $(D)$, outer lateral teeth $(E) . F$, Postradular armature of a specimen from Islas Secas, Panama (LACM 1935-86.13). G, H, Gizzard plates of a specimen from Islas Secas, Panama (LACM 1935-86.13). I, Gizzard plate of a specimen from Puerto Parker, Costa Rica (LACM 135-108.4).

as penial canal, located at distal end of male organ. Penis wide and elongate, conical, curved apically, with longitudinal groove (Fig. 15B, E, $H$ ) and numerous minute spines (Fig. $15 F, I$ ). Vagina with large rounded structures bearing conical spines on centres (Fig. 16).

\section{Range}

Eastern Pacific Ocean, from Baja California to Galápagos Islands.

\section{Remarks}

MacFarland (1966) described Aclesia rickettsi based on specimens collected by E. F. Ricketts in the Gulf of
California. The animals were preserved, thus no information on the external coloration was provided. MacFarland (1966) provided a description of the internal anatomy, which is consistent with the characteristics of the specimens of Stylocheilus here examined. Stylocheilus has been reported from the Gulf of California where it is very abundant in the La Paz area (Angulo Campillo 2003). Because Aclesia rickettsi is the only available name introduced for eastern Pacific species of Stylocheilus and the original description matches the characteristics of the animals here examined, we propose using the name $S$. rickettsi for the eastern Pacific species. 


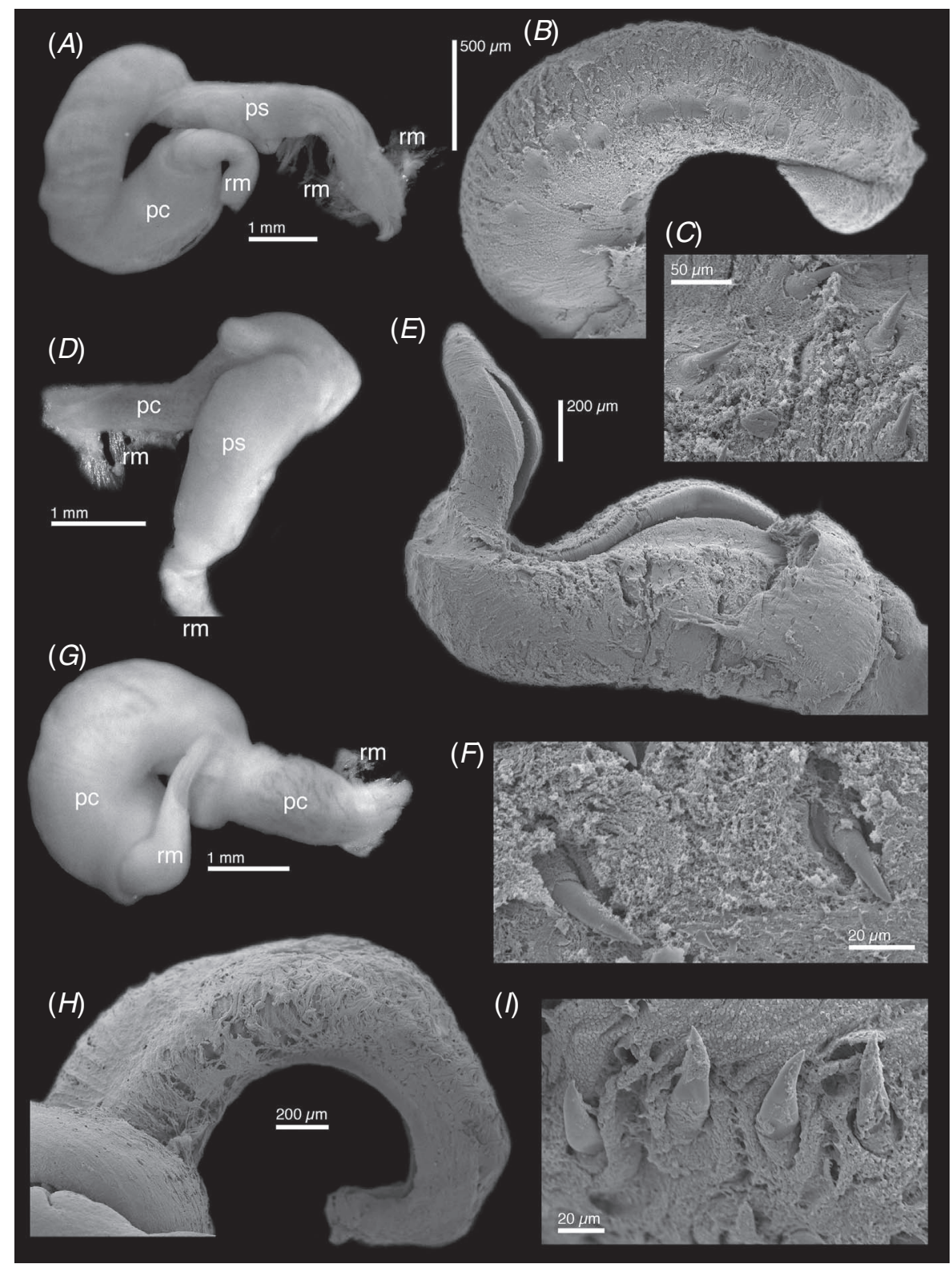

Fig. 15. Penial anatomy of Stylocheilus rickettsi (MacFarland, 1966), specimens from the Eastern Pacific region. $A-C$, Specimen from Puerto Parker, Costa Rica (LACM 135-108.4): complete male reproductive organs $(A)$, scanning electron micrograph (SEM) of the penis $(B)$, SEM detail of penial spines $(C) . D-F$, Specimen from Islas Secas, Panama (LACM 1935-86.13): complete male reproductive organs $(D)$, SEM of the penis $(E)$, SEM detail of penial spines $(F)$. $G-I$, Specimen from San Carlos Bay, Sonora, Mexico (LACM 24997): complete male reproductive organs $(G)$, SEM of the penis $(H)$, SEM detail of penial spines $(I)$. Abbreviations: rm, retractor muscle; pc, penial canal; ps, penial sheath.

\section{Genus Phycophila Adams, 1861}

Phycophila Adams, 1861: 141

Type species: Aplysia euchlora Adams, 1861, by subsequent designation by Pilsbry $(1895,1896)$.

\section{Diagnosis}

Body oval, soft, with broad and short triangular posterior end of foot (metapodium). Body surface, rhinophores, and oral tentacles covered with numerous papillae, simple or ramified. Mantle cavity with fairly large opening, containing large gill, surrounded or covered by short parapodia. Shell flat, calcified, with curved apex. Radula with broad rachidian teeth and numerous denticulate lateral teeth. Penis very elongate, armed with minute spines; penial canal unarmed.

\section{Remarks}

Gray (1850, pl. 179) illustrated two sea hares in a black and white plate, thus no colour information is available. The 

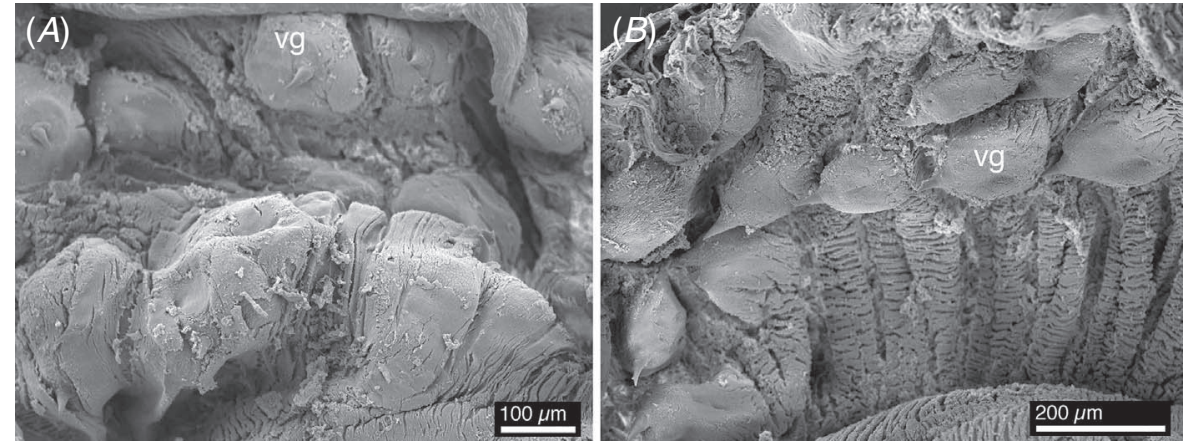

Fig. 16. Vaginal spines of Stylocheilus rickettsi (MacFarland, 1966), specimens from the Eastern Pacific region. $A$, Specimen from Islas Secas, Panama (LACM 1935-86.13). B, Specimen from Puerto Parker, Costa Rica (LACM 135-108.4).

drawings represent two animals crawling or resting on seagrass leafs, and both animals appear to have smooth bodies and elongate tails. The right figure was captioned as 'Placobranchus euchlorus. Mr. Adams drawing. Borneo' and the left figure as ' $P$. ocellatus (Van Hasselt) Mr. Adams drawing. Borneo.' Subsequently, Adams (1861) introduced the species name Aplysia (Phycophila) euchlora Adams, 1861 for the animal illustrated in the right figure by Gray (1850: pl. 179) and described it as a green Aplysia, compressed, with a narrow foot, elongate anterior tentacles and narrow posterior tentacles with truncate apices, and an elongate tail. Adams (1861) stated that he had observed this species on floating Zostera during the voyage of the 'Samarang' and that the specimens were collected in the 'Straits of Tsugar or Tseuka'. Pilsbry $(1895,1896)$ interpreted this locality as Tsugaru Strait, Japan, but the H.M.S. Samarang only visited 'Loo-Choo' [=Ryukyu Islands] and 'Nangasaki' [=Nagasaki], both in southern Japan. Thus, most likely this species was found in tropical or subtropical waters. Adams (1861) described the shell of Aplysia (Phycophila) euchlora as membranous, oblong, with a non-involute apex. Adams (1861) also introduced the new species name Aplysia ocellata for the specimen represented in the left figure by Gray (1850, pl. 179) and commented that it is a member of the same subgenus Phycophila. Aplysia ocellata Adams, 1861 is preoccupied by Aplysia ocellata d'Orbigny, 1839, so Pilsbry (1895, 1896) introduced the name Tethys adamsi Pilsbry, 1896 to replace Aplysia ocellata Adams, 1861. There is no mention of these two species names in the description of the "Voyage of the Samarang' by Adams and Reeve (1850). Pilsbry (1895, 1896) commented that the placement of Phycophila is difficult and if it were not for the presence of a shell, he would have considered it as a synonym of Stylocheilus; he also designated Aplysia euchlora Adams, 1861 as the type species.

In this paper, we have identified a clade of Stylocheilus-like organisms that possess a shell in the mantle cavity, similar to that of other species of Aplysiidae. The genus Phycophila is the only taxon with similar characteristics having a shell, and therefore we consider that is it most appropriate to use the name for the species here studied. Because Phycophila is closely related to Stylocheilus and these two groups form a monophyletic group, these two names could be synonymised. However, this would entail changing the diagnosis of Stylocheilus to accommodate species with an internal shell. We think it is in the best interest of nomeclatural stability to resurrect an already available name, avoiding diagnostic changes to widely used names.

\section{Phycophila euchlora Adams, 1861}

(Fig. 2D, E, 17, 18)

Aplysia (Phycophila) euchlora Adams, 1861: 141 [Gray 1850, pl. 179, right].

Type locality: 'Straits of Tsugar or Tseuka.'

Type material

Aplysia (Phycophila) euchlora Adams, 1861, location unknown, not at NHMUK (A. Salvador, pers. comm.).

\section{Material examined}

Bigej-Meck Reef, Kwajalein Atoll, Marshall Islands, 6.viii.2011, 1 specimen 13-mm preserved length, leg. Scott and Jeanette Johnson (CASIZ 188009).

\section{Description}

External morphology. Body narrow, elongate, with conical posterior end of foot (metapodium) occupying nearly $1 / 3$ of the body length. Parapodia reduced, fused together anteriorly and posteriorly, leaving visible large portion of shell and gill. Parapodia region of body enlarged, forming a conspicuous dorsal bump. Body covered with several highly ramified papillae, variable in size and shape. Primary papillae typically few, long, tentacular, with numerous secondary branches (Fig. 2D, E); secondary branches shorter than papillae, forming dense, feather-like structures. Dorso-anterior rhinophores, enrolled, tentacular, elongate. Oral tentacles anterior, much shorter and blunter than rhinophores. Rhinophores and oral tentacles covered with papillae, shorter and less numerous than those on body surface. Colour brownish grey. Body surface with numerous small black dots, opaque white patches irregularly arranged, and few bright blue spots surrounded with black rings. Papillae with same colour as body, but typically lighter. 


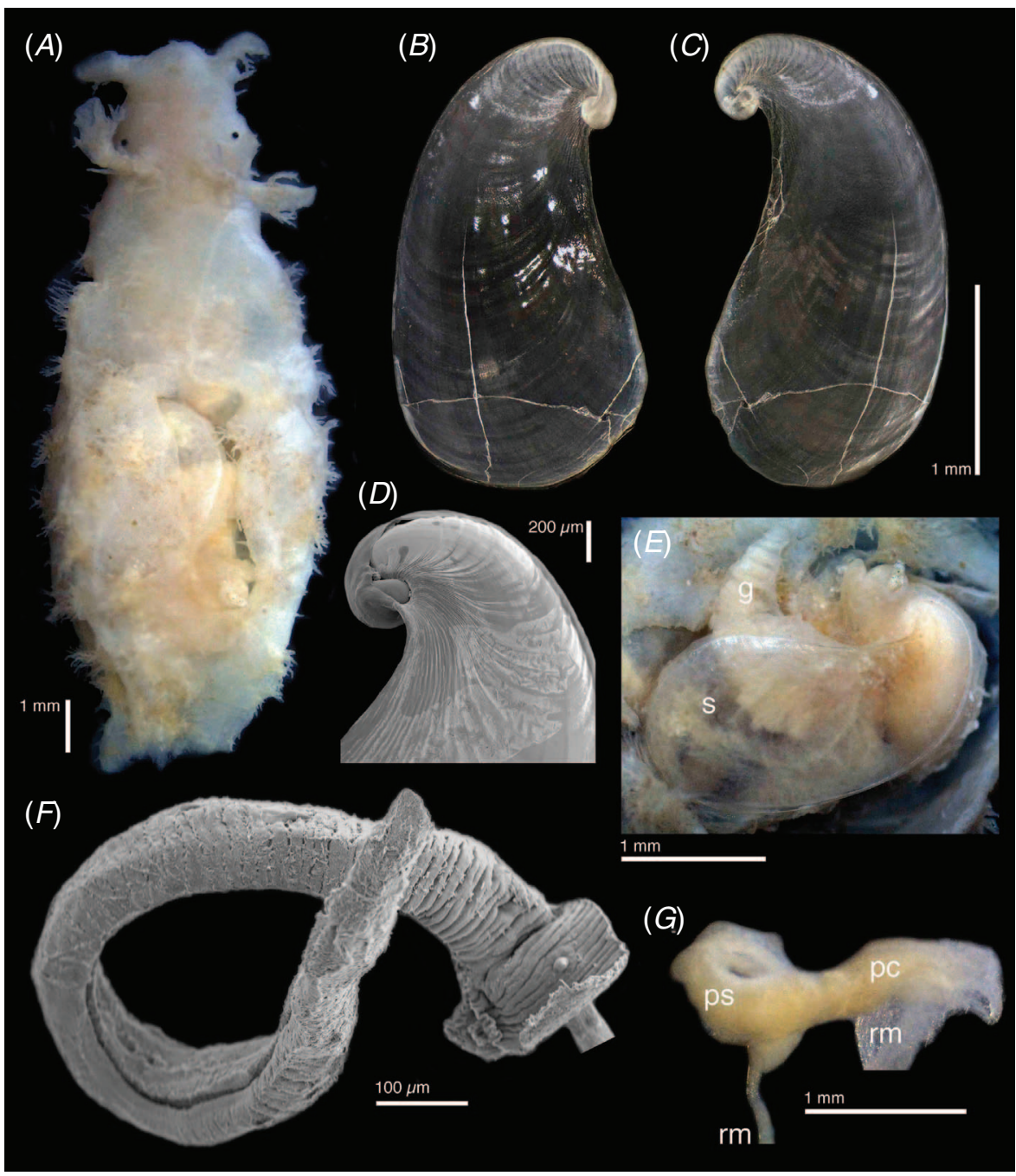

Fig. 17. External morphology and anatomy of Phycophila euchlora Adams, 1861, specimen from the Marshall Islands (CASIZ 188009) (EN101). A, Preserved specimen. $B, C$, Dorsal and ventral view of the shell. $D$, scanning electron micrograph (SEM) of the shell apex. $E$, Shell on the preserved specimen. $F$, SEM of the penis. $G$, Complete male reproductive organs. Abbreviations: g, gill; rm, retractor muscle; s, shell; pc, penial canal; ps, penial sheath.

Internal morphology. Shell flat, elongate, semitransparent, curved posteriorly (Fig. 17B,C), partially covered by left parapodium (Fig. 17A), covering part of gill (Fig. 17E). Shell apex with protoconch partially visible (Fig. 17D). Radular formula $22 \times 16.1 .16$ in 13-mm-long specimen from the Marshall Islands (CASIZ 188009). Rachidian teeth with robust, wide central cusp bearing sharp central denticle plus 3 lateral denticles on each side, each with variable number of smaller secondary denticles (Fig. 18A). Base of rachidian teeth much wider than cusp, triangular with concave proximal end. Innermost lateral teeth with central cusp surrounded by large blunt denticle on each side (Fig. 18A). Mid-lateral teeth with short, blunt cusp and several blunt denticles on outer side (Fig. 18B). Outermost lateral teeth with very elongate cusp, and numerous sharp denticles (Fig. 18C). Jaws composed of numerous, simple elements (Fig. 18D). Gizzard with several irregular plates (Fig. 18E-G). Postradular armature not observed. Male copulatory organ with elongate penial canal and strong anterior and posterior retractor muscles (Fig. 17G). Penial sheath located at distal end of male organ. Penis very elongate, narrow, smooth, lacking penial spines, with longitudinal groove (Fig. 17F).

\section{Range}

Probably originally described from southern Japan and subsequently reported from the Hawaiian Islands (Pittman and Fiene 2005), the species is here reported from the Marshall Islands and French Polynesia.

\section{Remarks}

As indicated in the remarks of the genus Phycophila, we are proposing to resurrect this name for a group of Stylocheiluslike animals with a shell. In this study we have sequenced two 

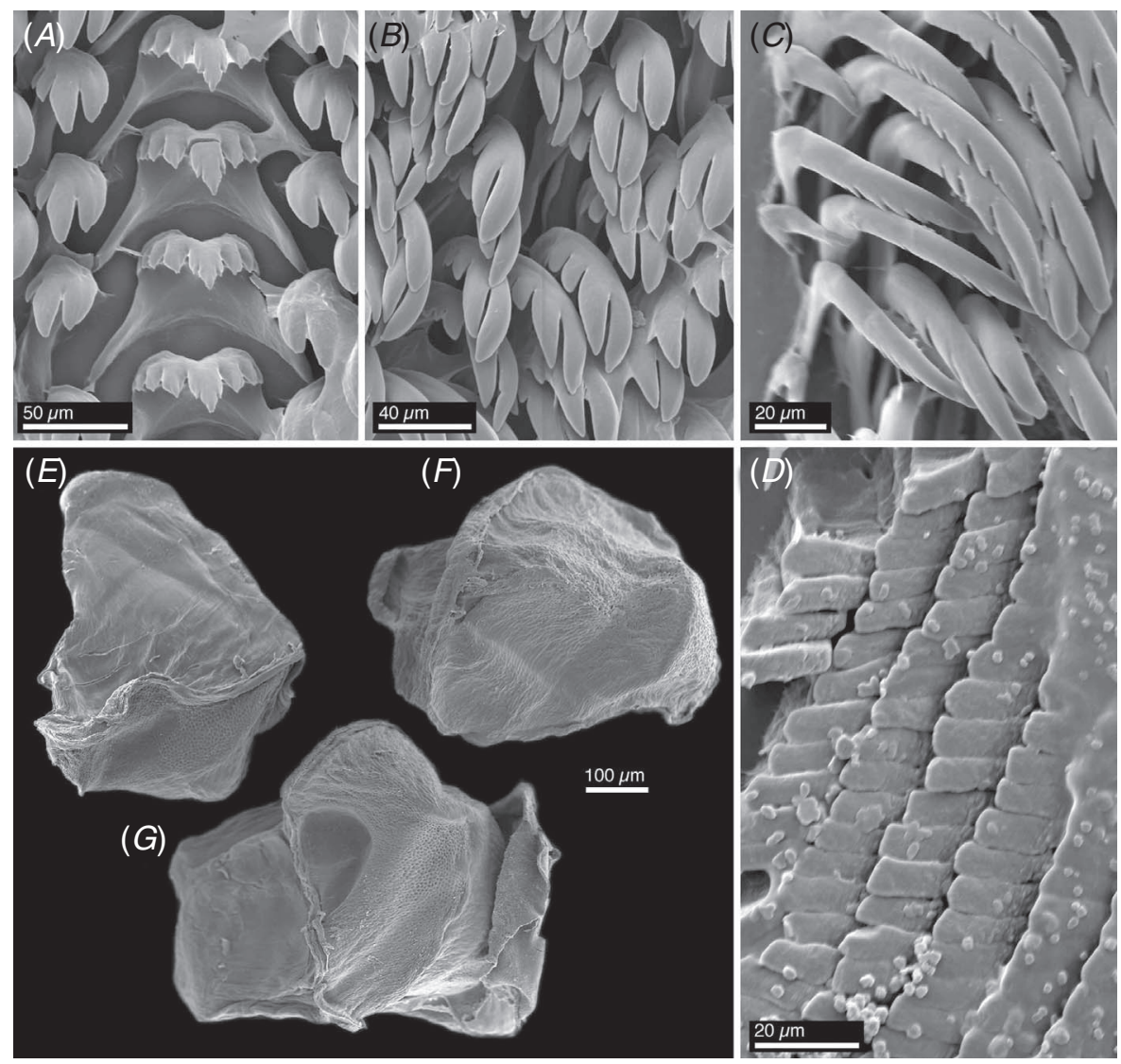

Fig. 18. Scanning electron micrographs of the anatomy of Phycophila euchlora Adams, 1861, specimen from the Marshall Islands (CASIZ 188009) (EN101). $A-C$, Radular teeth; rachidian and inner lateral teeth $(A)$, mid-lateral teeth $(B)$, outer lateral teeth $(C)$. $D$, Jaw elements. $E-G$, Gizzard plates.

specimens, which form a monophyletic group and are recovered as a single species in the species delimitation analyses. Based on external similarities with the original description of Phycophila euchlora Adams, 1861 and the presence of a shell, we propose to use this species name for our specimens. One of the specimens from the Marshall Islands was examined morphologically and illustrated in this study. For the second specimen, we had access to sequences from material collected in French Polynesia only, but the specimen was not available for morphological examination. Pittman and Fiene (2005) reported this species from the Hawaiian Islands as Stylocheilus(?) sp. \#1 and illustrated the shell, which is nearly identical to that of the specimen from the Marshall Islands here examined.

Aplysia cirrhifera Quoy \& Gaimard, 1832 is externally very similar to Phycophila euchlora and it could be a synonym. However, there is no evidence of the presence of a shell in the original description (Quoy and Gaimard 1832) or in the type material (M. Caballer, pers. comm.). Therefore, we maintain this name in the synonymy of Bursatella leachii (see above).

\section{Discussion}

Systematics and updated taxonomy

The results of this study indicate that the genera Bursatella and Stylocheilus, as presently understood, comprise more than one benthic species each. A review of the literature has shown that available names existed for all the taxa recognised in the present study, thus no new species names have been introduced herein. Species delimitation analyses recovered two morphologically distinct taxa in Bursatella, a nearly pantropical species (B. leachii) and an Indo-Pacific endemic (B. ocelligera). Three distinct taxa have been recovered for Stylocheilus, an Atlantic species (S. polyomma), an Indo-Pacific species (S. striatus), and an eastern Pacific species (S. rickettsi). Additionally, phylogenetic analyses recovered a third clade, comprising a specimen previously identified as Bursatella and a GenBank sequence attributed to Stylocheilus, which is here recognised as a distinct genus. The name Phycophila was resurrected for this genus, which contains a single species ( $P$. euchlora), collected from the Marshall Islands (present study), French Polynesia, and possibly the Hawaiian Islands (Pittman and Fiene 2005).

Consistent morphological differences have been documented among populations of $B$. leachii from distinct 
geographic areas (Eales and Engel 1935), leading these authors to characterise several regional subspecies. Particularly noticeable is the distinct external morphology of the South African specimen (Fig. 2B) analysed in this study. Differences in the external morphology and coloration can, however, also be observed among specimens collected from the same region (Selfati et al. 2017 and references therein). In the present study, no consistent genetic differences in the loci analysed have been observed among populations of $B$. leachii from different regions, with the exception of differences in $\mathrm{COI}$ sequences between Atlantic and Indo-Pacific specimens. Therefore, we propose that all of the subspecies names listed in Eales and Engel (1935) should be synonymised under $B$. leachii. The significance of the genetic differences between Indo-Pacific and Atlantic specimens, and their importance in the identification of the source population of the recent colonisation of the Mediterranean by B. leachii, have been recently discussed by Bazzicalupo et al. (2018).

\section{Biogeography}

There are several important differences between Bursatella and Stylocheilus in regard to the geographic range of the newly recognised species. Stylocheilus displays a geographic pattern consistent with the sequence of events leading to the final break-up of the Tethys Sea and the interruption of east-west communication across tropical seas (see Valdés 2004). Without a properly calibrated molecular-clock analysis, the split times of the different Stylocheilus lineages cannot be determined. Additionally, our analyses failed to resolve the relationships between the three Stylocheilus species, with low support for one topology in the concatenated analysis, and different scenarios recovered in the single-gene trees. Without data from additional markers, the only clear pattern is that two successive vicariance events have split Stylocheilus into three distinct lineages, resulting in allopatric taxa distributed in three different ocean basins: Indo-Pacific, Atlantic, and Eastern Pacific. Variations of the same theme were found in other recent studies (Ornelas-Gatdula et al. 2012; Alexander and Valdés 2013; Carmona et al. 2014b). On the contrary, the geographic distribution pattern in Bursatella is more unusual. First of all, Bursatella is absent from the Central and Eastern Pacific. Second, one of the species, $B$. leachii, has a range that includes both the Atlantic and the Indo-Pacific. This is not just an unusually broad range, spanning uninterruptedly from the Caribbean Sea to the tropical waters of Japan, passing through the waters of South Africa - a distributional span of over $20000 \mathrm{~km}$ - but no other species complex of heterobranch sea slug examined to date contains species with a range comprising the Atlantic and Indo-Pacific (Ornelas-Gatdula et al. 2012; Alexander and Valdés 2013; Krug et al. 2013; Carmona et al. 2014a, 2014b; Goodheart et al. 2015; Kienberger et al. 2016; Valdés et al. 2017). The only exception is the pelagic species Glaucus atlanticus Forster, 1777 (Churchill et al. 2014) which is also present in the Atlantic and Indo-Pacific and, as in the case of B. leachii, is present in South Africa. Churchill et al. (2014) hypothesised that South African waters might have acted as a link between the Atlantic and Indian Ocean's populations of G. atlanticus, through a process known as the Agulhas Leakage (Vermeij
2012). This mechanism of faunal exchange between the two ocean basins is believed to be caused by an enhancement of the Agulhas Current around the tip of South Africa regulated by oscillations of global temperatures during interglacial periods (Churchill et al. 2014). This process could also explain the range of $B$. leachii, resulting in cross-oceanic gene flow and preventing the complete separation of the Indo-Pacific and Atlantic lineages. Moreover, the small but consistent divergence in $C O I$ sequence data between Indo-Pacific and Atlantic B. leachii (Bazzicalupo et al. 2018) suggests that this process was active in the past but has been interrupted. The absence of Stylocheilus from South African waters could possibly explain the difference in distributional pattern we observed between Bursatella and Stylocheilus. Because of the more strictly tropical distribution of Stylocheilus and its inability to survive in colder waters, such those in South Africa, the southern tip of Africa would represent an impenetrable barrier to gene flow, leading to the maintenance of distinct Atlantic and Indo-Pacific lineages.

\section{Speciation and evolution}

The presence of sympatrically co-occurring sister species in the Indo-Pacific, such as Bursatella leachii and B. ocelligera, suggests that speciation might have occurred because of nongeographic mechanisms of isolation. If the two species have evolved sympatrically, the differences in the morphology of the penis, unarmed in $B$. ocelligera, are suggestive of reproductive isolation because of differences in reproductive morphology as a possible driver of isolation between the two taxa. An alternative hypothesis is that $B$. leachii and $B$. ocelligera might have evolved allopatrically in the Atlantic and Indo-Pacific respectively, followed by dispersal of $B$. leachii into the Indo-Pacific (secondary sympatry). Further investigation on the ecology and behaviour is needed in order to test these hypotheses (sympatric speciation $v$. secondary sympatry) and understand the mechanisms that have driven the separation of the two Bursatella lineages.

The presence of a shell in the adult form of $P$. euchlora was a key characteristic used to substantiate that this species belongs to a genus different from Bursatella, Stylocheilus, and other closely related genera such a Notarchus. The presence of an adult shell is a readily detectable trait for the identification of this newly resurrected species. The reduction or loss of an adult shell is considered to be a homoplastic trait in the Aplysiida (Medina and Walsh 2000). In light of the rediscovery of Phycophila, phylogenetic relationships with other members of Aplysiida should be reassessed in order to understand how the adult shell trait has been preserved or lost along their evolutionary history. Additional sampling of taxa and genetic loci may further confirm the shell loss as a homoplasy in this clade and provide tools to investigate the evolutionary events that led to the loss of an adult shell in these organisms.

\section{Future research}

The distinct geographic structure of Bursatella and Stylocheilus make this clade an interesting system to study 
comparative biogeography and examine the mechanisms of speciation in closely related groups with different ecologies.

Whereas Bursatella has colonised the Mediterranean, most likely from tropical Atlantic populations (Bazzicalupo et al. 2018), Stylocheilus has not. Even though benthic and pelagic species of Stylocheilus are present in both the Red Sea (Yonow 2008) and the Canary Islands (Ortea et al. 2008), and favourable conditions have allowed the dispersal of several other species of sea slugs across the Suez Canal (Crocetta et al. 2013; Zenetos et al. 2017) and the Gibraltar Strait (Valdés et al. 2013), something must be preventing species of Stylocheilus from making such a move. Again, this is a case of two closely related lineages, each with species with broad dispersal abilities, but with different responses to recent environmental or physical changes. Comparative ecology studies in these two groups may reveal key biological factors that promote invasion.

The pelagic species of Stylocheilus - S. longicaudus (Quoy \& Gaimard, 1825) - has not been treated in this study. Because of its pelagic nature, specimen collection requires different methodologies and additional effort. S. longicaudus could be a single pantropical species or could also constitute a species complex; alternatively, it could be an ecotype of the benthic species resulting from a pelagic lifestyle. Further investigations of Stylocheilus should attempt to include samples of $S$. longicaudus from different ocean basins, in order to obtain a more complete picture of the evolution of Stylocheilus and the evolution of the pelagic lifestyle.

\section{Conflicts of interest}

The authors declare that they have no conflicts of interest.

\section{Declaration of funding}

The TROPIMUNDO Steering Board provided funding for traveling expenses through the TROPIMUNDO Thesis Grant. The scanning electron microscope work was conducted at the California State Polytechnic University Scanning Electron Microscope Laboratory supported by the US National Science Foundation (NSF) grant DMR-1429674. Field work in the Hawaiian Islands and Panama was supported by the NSF grant DEB-1355177. Part of the molecular work done by Y. E. Camacho-García was funded by PEET Grant DEB9978155 to T. M. Gosliner and Á. Valdés and carried out at the facilities of the Center for Comparative Genomics (CCG) at the California Academy of Sciences (CAS). Other molecular work by Y. E. Camacho-García was founded by the CIEMIC projects $810-\mathrm{B} 8-204,810-\mathrm{B} 1-136$, and the CIMAR projects 808-B7-14, 808-B3-092 of Vicerrectoría de Investigación (University of Costa Rica) and carried out at the Molecular Laboratory at CIMAR.

\section{Acknowledgements}

Hessam Ghanimi, Jennifer McCarthy, and Sabrina Medrano (California State Polytechnic University, USA) greatly helped with laboratory work. Elena Tricarico (University of Florence) supervised E. Bazzicalupo's work during his Master thesis. Museum information and specimens were provided by several individuals: Albé Bosman (South African Museum), Elizabeth Kools (CASIZ), Lindsey Groves (LACM), Adreia Salvador (NHMUK), Kathe Jensen (NHMD), and Manuel Caballer
(MNHN). We also thank the Museo de Zoología (Universidad de Costa Rica) for providing access to the specimens and SINACMINAET for approving the collecting permits in Costa Rica. Kimberly García collected the specimens of Stylocheilus in Cocos Island. We are grateful to several collectors for providing specimens from various localities, including G. Siu and S. Mills (French Polynesia), A. DuPont (Jamaica), and A. Dimitris (Florida).

\section{References}

Adams, A. (1861). On some new species of Mollusca from the north of China and Japan. Annals \& Magazine of Natural History, Series 3 8(44), 135-142. doi:10.1080/00222936108697389

Adams, A., and Reeve, L. (1850). Mollusca. In 'The Zoology of the Voyage of H.M.S. Samarang; under the Command of Captain Sir Edward Belcher, C.B., F.R.A.S., F.G.S., During the Years 1843-1846'. (Ed. A. Adams.) pp. i-x, 1-87. (Reeve and Benham: London, UK.)

Alexander, J., and Valdés, A. (2013). The ring doesn't mean a thing: molecular data suggest a new taxonomy for two Pacific species of sea hares (Mollusca: Opisthobranchia, Aplysiidae). Pacific Science 67, 283-294. doi:10.2984/67.2.10

Allan, J. K. (1932). A new genus and species of sea-slug, and two new species of sea-hares from Australia. Records of the Australian Museum 18, 314-320. doi:10.3853/j.0067-1975.18.1932.736

Angulo Campillo, O. J. (2003). Variación espacio-temporal de las poblaciones de opistobranquios (Mollusca Opistobranchia) en tres localidades de B.C.S., México. Unpublished M.S. Dissertation, Instituto Politécnico Nacional, Centro Interdisciplinario de Ciencias Marinas, La Paz, Mexico.

Armstrong, E. J., Allen, T. R., Beltrand, M., Dubousquet, V., Stillman, J. H., and Mills, S. C. (2017). High $\mathrm{pCO}_{2}$ and elevated temperature reduce survival and alter development in early life stages of the tropical sea hare Stylocheilus striatus. Marine Biology 164, 107. doi:10.1007/s00227017-3133-x

Audouin, J. V. (1826). Explication sommaire des planches de mollusques de l'Egypte et de la Syrie, publiées par Jules-César Savigny, membre de l'Institut; offrant un exposé des caractères naturels des genres avec la distinction des espèces. In 'Book 8. Histoire Naturelle. Vol. 1, Part 4. Description de l'Égypte: ou Recueil des Observations et des Recherches qui Ont Eté Faites en Égypte Pendant L'expédition de l'Armée Française, Publié par les Ordres de Sa Majesté l'Empereur Napoléon le Grand'. (Ed. E. F. Jomard.) pp. 7-56. (L'Imprimerie Impériale: Paris, France.)

Bazzicalupo, E., Crocetta, F., Estores-Pacheco, K. A., Golestani, H., Bazairi, H., Giacobbe, S., Jaklin, A., Poursanidis, D., Chandran, S. B. K., Cervera, J. L., and Valdés, A. (2018). Population genetics of Bursatella leachii (De Blainville, 1817) and implications for the origin of the Mediterranean population. Helgoland Marine Research 72, 19. doi:10.1186/s10152-018-0521-7

Bebbington, A. (1969). Bursatella leachi guineensis subsp. nov. (Gastropoda, Opisthobranchia) from Ghana. Proceedings of the Malacological Society of London 38, 323-341.

Bebbington, A. (1974). Aplysiid species from East Africa with notes on the Indian Ocean Aplysiomorpha (Gastropoda: Opisthobranchia). Zoological Journal of the Linnean Society 54, 63-99. doi:10.1111/ j.1096-3642.1974.tb00793.x

Bebbington, A. (1977). Aplysiid species from eastern Australia with notes on the Pacific Ocean Aplysiomorpha (Gastropoda, Opisthobranchia). Journal of Zoology 34, 87-147.

Bendell, B. E. (2006). Interactions amongst invertebrates, epiphytes, and seagrasses in tropical intertidal meadows. Ph.D. Thesis, James Cook University, Townsville, Qld, Australia.

Bergh, R. (1902a). Malacologische Untersuchungen. In 'Reisen im Archipel der Philippinen. Ascoglossa, Aplysiidae. Vol. 7. Section 4.' (Ed. 
C. Semper.) pp. 339-370, pl. 28-29. (Kreidel's Verlag: Wiesbaden, Germany.)

Bergh, R. (1902b). The Danish Expedition to Siam 1899-1900. I. Gasteropoda Opisthobranchiata. Det Kongelige Danske Videnskabernes Selskabs Skrifter, Series 6 12, 159-218.

Bergh, R. (1907). The Opisthobranchia of South Africa. Transactions of the South African Philosophical Society 17, 1-144. doi:10.1080/ 21560382.1907.9526085

Bidgrain, P. (2017). Sea slugs from the south west Indian Ocean. Available at $\mathrm{http} / / /$ seaslugs.free.fr/nudibranche/a_intro.htm [Verified 22 January 2019].

Block, G. D., and Roberts, M. H. (1981). Circadian pacemaker in the Bursatella eye: properties of the rhythm and its effect on locomotor behavior. Journal of Comparative Physiology 142, 403-410. doi:10.1007/BF00605452

Capper, A., and Paul, V. J. (2008). Grazer interactions with four species of Lyngbya in southeast Florida. Harmful Algae 7, 717-728. doi:10.1016/ j.hal.2008.02.004

Capper, A., Tibbetts, I. R., O’Neil, J. M., and Shaw, G. R. (2005). The fate of Lyngbya majuscula toxins in three potential consumers. Journal of Chemical Ecology 31, 1595-1606. doi:10.1007/s10886-005-5800-5

Carmona, L., Bhave, V., Salunkhe, R., Pola, M., Gosliner, T. M., and Cervera, J. L. (2014a). Systematic review of Anteaeolidiella (Mollusca, Nudibranchia, Aeolidiidae) based on morphological and molecular data, with a description of three new species. Zoological Journal of the Linnean Society 171, 108-132. doi:10.1111/zoj.12129

Carmona, L., Lei, B. R., Pola, M., Gosliner, T. M., Valdés, A., and Cervera, J. L. (2014b). Untangling the Spurilla neapolitana (Delle Chiaje, 1841) species complex: a review of the genus Spurilla Bergh, 1864 (Mollusca: Nudibranchia: Aeolidiidae). Zoological Journal of the Linnean Society 170, 132-154. doi:10.1111/zoj.12098

Cheeseman, S. T. (1878). Descriptions of three new species of Opisthobranchiate Mollusca from New Zealand. Proceedings of the Zoological Society 1878, 275-277.

Churchill, C. K., Valdés, A., and Foighil, D. O. (2014). Afro-Eurasia and the Americas present barriers to gene flow for the cosmopolitan neustonic nudibranch Glaucus atlanticus. Marine Biology 161, 899-910. doi:10.1007/s00227-014-2389-7

Clarke, C. L. (2006). The population dynamics and feeding preferences of Bursatella leachii (Opisthobranchia: Anaspidea) in northeast Queensland, Australia. Records of the Western Australian Museum 69, 11-21. doi:10.18195/issn.0313-122x.69.2006.011-021

Cockerell, T. D. A. (1893). On a new species of Aplysiidae from Jamaica. Annals \& Magazine of Natural History, Series 6 11(63), 218-220. doi:10.1080/00222939308677501

Colgan, D. J., Ponder, W. F., and Eggler, P. E. (2000). Gastropod evolutionary rates and phylogenetic relationships assessed using partial $28 S$ rDNA and histone $H 3$ sequences. Zoologica Scripta 29, 29-63. doi:10.1046/j.1463-6409.2000.00021.x

Crocetta, F., Zibrowius, H., Bitar, G., Templado, J., and Oliverio, M. (2013). Biogeographical homogeneity in the eastern Mediterranean Sea - I: The opisthobranchs (Mollusca: Gastropoda) from Lebanon. Mediterranean Marine Science 14, 403-408. doi:10.12681/mms.404

Cunha, C. M., and Simone, L. R. L. (2019). Morphological re-description of Aplysia depilans (Gastropoda: Anaspidea): new insights into the anatomy of the anaspideans. Journal of the Marine Biological Association of the United Kingdom 99(3), 595-610. doi:10.1017/ S0025315418000528

Dance, S. P. (1966). 'Shell Collecting: An Illustrated History.' (University of California Press: Berkeley, USA.)

Darriba, D., Taboada, G. L., Doallo, R., and Posada, D. (2012). jModel-Test 2: more models, new heuristics and parallel computing. Nature Methods 9, 772. doi:10.1038/nmeth.2109 de Blainville, H. M. D. (1817). Bursatella (Supplément p. 138). In 'Dictionnaire des Sciences Naturelles, dans Lequel on Traite Méthodiquement des Différens Etres de la Nature, Considérés soit en Eux-mêmes, d'Après l'Etat Actuel de nos Connoissances, Soit Relativement a l'Utilité qu'en Peuvent Retirer la Médecine, L'agriculture, le Commerce et les Arts, Suivi d'une Biographie des plus Célèbres Naturalistes. Vol. 5'. (F.G. Levrault : Strasbourg, France.) de Blainville, H. M. D. (1825). 'Manuel de Malacologie et de Conchyliologie. Vol. 1.' (F.G. Levrault: Paris, France.)

de Blainville, H. M. D. (1827). 'Manuel de Malacologie et de Conchyliologie. Vol. 2, Planches.' (F.G. Levrault: Paris, France.)

Eales, N. (1952). On Barnardaclesia cirrhifera Q. \& G. Proceedings of the Malacological Society of London 29, 71-79.

Eales, N., and Engel, H. (1935). The genus Bursatella de Blainville. Proceedings of the Malacological Society of London 21, 279-303.

Engel, H. (1926). Drei neue Arten der Gattung Aclesia (Rang) Bergh 1902. Zoologischer Anzeiger 64, 181-187.

Engel, H. (1927). Westindische Opisthobranchiate Mollusken. In 'Bijdragen tot de Kennis der Fauna van Curaçao. Resultaten eener Reis van Dr C. J. van der Horst in 1920. II. Aplysiidae, Pleurobranchidae, Oxynoeidae, Elysiidae, Phyllobranchidae'. Bijdragen tot de Dierkunde 25, 83-122. doi:10.1163/2666064402501004

Folmer, O., Black, M., Hoeh, W., Lutz, R., and Vrijenhoek, R. (1994). DNA primers for amplification of mitochondrial cytochrome $c$ oxidase subunit I from diverse metazoan invertebrates. Molecular Marine Biology and Biotechnology 3, 294-299.

Gallimore, W. A., and Scheuer, P. J. (2000). Malyngamides O and P from the sea hare Stylocheilus longicauda. Journal of Natural Products 63, 1422-1424. doi:10.1021/np0000365

Golestani, H., Crocetta, F., Padula, V., Camacho-García, Y., Langeneck, J., Poursanidis, D., Pola, M., Yokeş, M. B., Cervera, J. L., Jung, D.-W., Gosliner, T. M., Araya, F., Hooker, Y., Schrödl, M., and Valdés, A. (2019). The little Aplysia's coming of age: from one species to a complex of species complexes in Aplysia parvula Mörch, 1863 (Mollusca, Gastropoda, Heterobranchia). Zoological Journal of the Linnean Society 187(2), 279-330. doi:10.1093/zoolinnean/ zlz028

Goodheart, J., Camacho-García, Y., Padula, V., Schrödl, M., Cervera, J. L., Gosliner, T. M., and Valdés, A. (2015). Systematics and biogeography of Pleurobranchus Cuvier, 1804, sea slugs (Heterobranchia: Nudipleura: Pleurobranchidae). Zoological Journal of the Linnean Society 174, 322-362. doi:10.1111/zoj.12237

Gopichand, Y., and Schmitz, F. J. (1980). Bursatellin: a new diol dinitrile from the sea hare Bursatella leachii pleii. The Journal of Organic Chemistry 45(26), 5383-5385. doi:10.1021/jo01314a040

Gosliner, T. M. (1987). 'Nudibranchs of Southern Africa. A Guide to Opisthobranch Mollusks of Southern Africa.' (Sea Challengers: Monterey, USA.)

Gosliner, T. M., Valdés, A., and Behrens, D. W. (2018). 'Nudibranch and Sea Slug Identification. Indo-Pacific', 2nd edn. (New World Publications, Inc.: Jacksonville, FL, USA.)

Gould, A. A. (1852). Mollusca \& shells. In 'United States Exploring Expedition. During the years 1838, 1839, 1840, 1841, 1842. Under the Command of Charles Wilkes, U.S.N., Vol. 12.' pp. i-xv, 1-510. (Gould and Lincoln: Boston, MA, USA.)

Gould, A. A. (1856). Atlas mollusca \& shells. In 'United States Exploring Expedition. During the years 1838, 1839, 1840, 1841, 1842. Under the Command of Charles Wilkes, U.S.N., Vol. 12'. pp. 1-16, pls. 1-52. (Gould and Lincoln: Boston, MA, USA.)

Gray, J. E. (1847). A list of the genera of recent Mollusca, their synonyma and types. Proceedings of the Zoological Society of London 15, 129-219. 
Gray, M. E. (1850). 'Figures of Molluscous Animals, Selected from Various Authors. Etched for the Use of Students. Vol 2.' (Longman, Brown, Green and Longmans: London, UK.)

Griffin, L. E. (1912). The anatomy of Aclesia freeri new species. Philippine Journal of Science 7, 65-90.

Hägg, R. (1904). Two new Opisthobranchiathe [sic.] Mollusca from the Red Sea. In 'Results of the Swedish Zoological Expedition to Egypt and the White Nile 1901 under the Direction of L. A. Jägerskiöld. Part 1'. (Ed. L. A. Jägerskiöld.) pp. 1-16, pl. 1. (The Library of the Royal University of Uppsala: Uppsala, Sweden.)

Hirase, S. (1934). 'A Collection of Japanese Shells with Natural Colours', 3rd edn. (Matsumura Sanshodo: Tokyo, Japan.)

Horwitz, R., Jackson, M. D., and Mills, S. C. (2017). The embryonic life history of the tropical sea hare Stylocheilus striatus (Gastropoda: Opisthobranchia) under ambient and elevated ocean temperatures. PeerJ 5, e2956. doi:10.7717/peerj.2956

Iredale, T.(1929). Strange molluscs in Sydney Harbour. Australian Zoologist 5, 337-352.

Johnson, R. I. (1964). The recent Mollusca of Augustus Addison Gould. Illustrations of the types described by Gould with a bibliography and catalogue of his species. Bulletin - United States National Museum 239, 1-182. doi:10.5479/si.03629236.239

Kienberger, K., Carmona, L., Pola, M., Padula, V., Gosliner, T. M., and Cervera, J. L. (2016). Aeolidia papillosa (Linnaeus, 1761) (Mollusca: Heterobranchia: Nudibranchia), single species or a cryptic species complex? A morphological and molecular study. Zoological Journal of the Linnean Society 177, 481-506. doi:10.1111/zoj.12379

Klussmann-Kolb, A. (2004). Phylogeny of the Aplysiidae (Gastropoda, Opisthobranchia) with new aspects of the evolution of seahares. Zoologica Scripta 33, 439-462. doi:10.1111/j.0300-3256.2004.00158.x

Kobelt, W. (1876). 'Illustrirtes Conchylienbuch.' (Bauer and Raspe: Nuremberg, Germany.)

Krug, P. J., Vendetti, J. E., Rodriguez, A. K., Retana, J. N., Hirano, Y. M., and Trowbridge, C. D. (2013). Integrative species delimitation in photosynthetic sea slugs reveals twenty candidate species in three nominal taxa studied for drug discovery, plastid symbiosis or biological control. Molecular Phylogenetics and Evolution 69, 1101-1119. doi:10.1016/j.ympev.2013.07.009

MacFarland, F. M. (1966). Studies of opisthobranchiate mollusks of the Pacific coast of North America. Memoirs of the California Academy of Sciences 6, 1-546.

Macnae, W. (1962). Tectibranch molluscs from southern Africa. Annals of the Natal Museum 15, 183-199.

Marcus, E. (1972). On the Anaspidea (Gastropoda: Opisthobranchia) of the warm waters of the western Atlantic. Bulletin of Marine Science 22, 841-874.

Medina, M., and Walsh, P. J. (2000). Molecular systematics of the order Anaspidea based on mitochondrial DNA sequence (12S, 16S, and COI). Molecular Phylogenetics and Evolution 15, 41-58. doi:10.1006/ mpev.1999.0736

Mörch, O. A. L. (1863). Contributions à la faune malacologique des Antilles danoises. Journal de Conchyliologie 11, 21-43.

O'Donoghue, C. H. (1929). Opisthobranchiate Mollusca collected by the South African Marine Biological Survey. Reports of Fisheries and Marine Biological Survey, Union of South Africa 7, 1-84.

Ornelas-Gatdula, E., Camacho-García, Y., Schrödl, M., Padula, V., Hooker, Y., Gosliner, T. M., and Valdés, A. (2012). Molecular systematics of the 'Navanax aenigmaticus' species complex (Mollusca, Cephalaspidea): coming full circle. Zoologica Scripta 41, 374-385. doi:10.1111/ j.1463-6409.2012.00538.x

Ortea, J., Moro, L., Bacallado, J. J., and Sánchez, J. J. (2008). Nuevas aportaciones a la fauna de opistobranquios (Mollusca: Gasteropoda) de las islas Canarias. Vieraea 36, 129-136.
Palumbi, S. R. (1996). Nucleic acids. II: The polymerase chain reaction. In 'Molecular Systematics', 2nd edn. (Eds D. M. Hillis, C. Moritz, and B. K. Mable.) pp. 205-247. (Sinauer: Sunderland, MA, USA.)

Paul, V. J., and Pennings, S. C. (1991). Diet-derived chemical defenses in the sea hare Stylocheilus longicauda (Quoy et Gaimard 1824). Journal of Experimental Marine Biology and Ecology 151, 227-243. doi:10.1016/0022-0981(91)90126-H

Pennings, S. C., Weiss, A. M., and Paul, V. J. (1996). Secondary metabolites of the cyanobacterium Microcoleus lyngbyaceus and the sea hare Stylocheilus longicauda: palatability and toxicity. Marine Biology 126, 735-743. doi: $10.1007 / \mathrm{BF} 00351340$

Pilsbry, H. A. (1895). 'Manual of Conchology, structural and systematic, with illustrations of the species, Vol. 16. Philinidae, Gastropteridae, Aglajidae, Aplysiidae, Oxynoeidae, Runcinidae, Umbraculidae, Pleurobranchidae', pp. 1-112. (Conchological Section, Academy of Natural Sciences of Philadelphia: Philadelphia, PA, USA.)

Pilsbry, H. A. (1896). 'Manual of Conchology, structural and systematic, with illustrations of the species, Vol. 16. Philinidae, Gastropteridae, Aglajidae, Aplysiidae, Oxynoeidae, Runcinidae, Umbraculidae, Pleurobranchidae', pp. 113-262, i-vii. (Conchological Section, Academy of Natural Sciences of Philadelphia: Philadelphia, PA, USA).

Pittman, C., and Fiene, P. (2005). Stylocheilus(?) sp. \#1. In 'Sea Slugs of Hawai'i'. Available at http://seaslugsofhawaii.com/species/Stylocheilussp1-a.html [Verified 22 January 2019].

Pruvot-Fol, A. (1934). Les opisthobranches de Quoy et Gaimard. Archives du Muséum national d' histoire naturelle 11(6), 13-89.

Quoy, J. R., and Gaimard, J. P. (1832). 'Voyage de la Corvette l'Astrolabe: Exécuté par Ordre du Roi, Pendant les Années 1826-1827-1828-1829 Sous le Commandement de J. Dumont d'Urville. Zoologie 2'. (J. Tastu: Paris, France.)

Quoy, J. R., and Gaimard, J. P. (1833). 'Voyage de la Corvette l'Astrolabe: Exécuté par Ordre du Roi, Pendant les Années 1826-1827-1828-1829 Sous le Commandement de M. Jules Dumont d'Urville Capitaine de Vaisseau. Zoologie, Atlas'. (J. Tastu: Paris, France.)

Rajaganapathi, J., Kathiresan, K., and Singh, T. P. (2002). Purification of anti-HIV protein from purple fluid of the sea hare Bursatella leachii de Blainville. Marine Biotechnology 4, 447-453. doi:10.1007/ s10126-002-0012-2

Ramos, L. J., Rocafort, J. L., and Miller, M. W. (1995). Behavior patterns of the aplysiid gastropod Bursatella leachii in its natural habitat and in the laboratory. Neurobiology of Learning and Memory 63, 246-259. doi:10.1006/nlme.1995.1029

Rang, S. (1828). Histoire naturelle des Aplysiens. Première famille de l'ordre des tectibranches. In 'Histoire Naturelle, Générale et Particulière des Mollusques, Tant des Espèces que l'on Trouve Aujourd'hui Vivantes, que des Dépouilles Fossiles de Celles qui N'existent Plus; Classés d'Après les Caractères Essentiels que Présentent ces Animaux et Leurs Coquilles'. (Ed. J. B. Ferrussac.) pp. 1-7, 1-83, pl. 1-24. (Bertrand: Paris, France.)

Rizgalla, J., and Crocetta, F. (2020). First confirmed record of the ragged sea hare Bursatella leachii Blainville, 1817 in Libyan waters. BioInvasions Records 9(2), 183-188. doi:10.3391/bir.2020.9.2.02

Ronquist, F., Teslenko, M., Van der Mark, P., Ayres, D. L., Darling, A., Höhna, S., Larget, B., Liu, L., Suchard, M. A., and Huelsenbeck, J. P. (2012). MrBayes 3.2: efficient Bayesian phylogenetic inference and model choice across a large model space. Systematic Biology 61, 539-542. doi:10.1093/sysbio/sys029

Rose, A. F., Springer, J. P., Clardy, J., and Scheuer, P. J. (1978). Stylocheilamide, an unusual constituent of the sea hare Stylocheilus longicauda. Journal of the American Chemical Society 100, 7665-7670. doi:10.1021/ja00492a039

Rudman, W. B. (1999). Stylocheilus longicauda \& Stylocheilus citrina. Nomenclatural discussion. In Sea Slug Forum, 3 August 1999. 
(Australian Museum: Sydney, NSW, Australia.) Available at http:// www.seaslugforum.net/factsheet/stylnome [Verified 22 January 2019].

Rudman, W. B. (2006). Comment on 'Is the genus Barnardaclesia valid?' In Sea Slug Forum, 2 February 2006. (Australian Museum: Sydney, NSW, Australia.) Available at http://www.seaslugforum.net/find/15721 [Verified 22 January 2019].

Rudman, W. B. (2007). Bursatella leachii subspecies. In Sea Slug Forum, 12 January 2007. (Australian Museum: Sydney, NSW, Australia.) Available at http://www.seaslugforum.net/find/19181 [Verified 22 January 2019].

Rüppell, E., and Leuckart, F. S. (1828). Mollusca. In 'Atlas zu des Reise im Nordlichen Afrika von Eduard Rüppell. 1. Abth. Zoologie. 5. Neue wirbellose Thiere des Rothen Meers'. (Ed. E. Rüppell.) pp. 1-22, pl. 1-12. (H. L. Brönner, Frankfurt, Germany.)

Rüppell, E., and Leuckart, F. S. (1830). Mollusca. In 'Atlas zu des Reise im Nordlichen Afrika von Eduard Rüppell. 1. Abth. Zoologie. 5. Neue wirbellose Thiere des Rothen Meers'. (Ed. E. Rüppell.) pp. 23-47. (H. L. Brönner, Frankfurt, Germany.)

Savigny, J. C. (1809). 'Description de l'Égypte: ou Recueil des Observations et des Recherches qui ont été Faites en Égypte Pendant L'expédition de l'Armée Française, Publié par les Ordres de Sa Majesté l'Empereur Napoléon le Grand. Book 18, Histoire Naturelle, Planches, Vol. 1.' (L'Imprimerie Impériale: Paris, France.)

Selfati, M., Ouamari, N. E., Crocetta, F., Mesfioui, A., Boissery, P., and Bazairi, H. (2017). Closing the circle in the Mediterranean Sea: Bursatella leachii Blainville, 1817 (Mollusca: Gastropoda: Anaspidea) has reached Morocco. BioInvasions Records 6, 129-134. doi:10.3391/bir.2017.6.2.07

Silvestro, D., and Michalak, I. (2012). raxmlGUI: a graphical front-end for RAxML. Organisms, Diversity \& Evolution 12,335-337. doi:10.1007/ s13127-011-0056-0

Stimpson, W. (1855). Descriptions of some of the new Marine Invertebrata from the Chinese and Japanese Seas. Proceedings. Academy of Natural Sciences of Philadelphia 7, 375-384.

Valdés, A. (2004). Phylogeography and phyloecology of dorid nudibranchs (Mollusca, Gastropoda). Biological Journal of the Linnean Society. Linnean Society of London 83, 551-559. doi:10.1111/j.10958312.2004.00413.x
Valdés, A., and Héros, V. (1998). The types of Recent and certain Fossil opisthobranch molluscs in the Muséum national d'Histoire naturelle, Paris. Zoosystema 20, 695-742.

Valdés, A., Alexander, J., Crocetta, F., Yokeş, M. B., Giacobbe, S., Poursanidis, D., Zenetos, A., Cervera, J. L., Caballer, M., Galil, B. S., and Schembri, P. J. (2013). The origin and dispersal pathway of the spotted sea hare Aplysia dactylomela (Mollusca: Opisthobranchia) in the Mediterranean Sea. Aquatic Invasions 8, 427-436. doi:10.3391/ ai.2013.8.4.06

Valdés, A., Breslau, E., Padula, V., Schrödl, M., Camacho, Y., Malaquias, M. A. E., Alexander, J., Bottomley, M., Vital, X. G., Hooker, Y., and Gosliner, T. M. (2017). Molecular and morphological systematics of Dolabrifera Gray, 1847 (Mollusca: Gastropoda: Heterobranchia: Aplysiomorpha). Zoological Journal of the Linnean Society 1847, 1-35.

Vermeij, G. J. (2012). The tropical history and future of the Mediterranean biota and the West African enigma. Journal of Biogeography 39, 31-41. doi:10.1111/j.1365-2699.2011.02601.x

Yonow, N. (2008). 'Sea Slugs of the Red Sea.' (Pensoft: Sofia, Bulgaria.)

Yonow, N. (2012). Opisthobranchs from the western Indian Ocean, with descriptions of two new species and ten new records (Mollusca, Gastropoda). ZooKeys 197, 1-129. doi:10.3897/zookeys.197.1728

Yonow, N., and Hayward, P. J. (1991). Opisthobranches de l'Ile Maurice, avec la description de deux espèces nouvelles (Mollusca: Opisthobranchia). Revue Franç̧aise d'Aquariologie 18, 1-30.

Zenetos, A., Çinar, M. E., Crocetta, F., Golani, D., Rosso, A., Servello, G., Shenkar, N., Turon, X., and Verlaque, M. (2017). Uncertainties and validation of alien species catalogues: the Mediterranean as an example. Estuarine, Coastal and Shelf Science 191, 171-187. doi:10.1016/j. ecss.2017.03.031

Zhang, J., Kapli, P., Pavlidis, P., and Stamatakis, A. (2013). A general species delimitation method with applications to phylogenetic placements. Bioinformatics 29, 2869-2876. doi:10.1093/bioinformatics/btt499

Zsilavecz, G. (2007). 'Nudibranchs of the Cape Peninsula and False Bay.' (Southern Underwater Research Group: Cape Town, South Africa.)

Handling editor: Manuel Malaquias 